\title{
Can a bog drained for forestry be a stronger carbon sink than a natural bog forest?
}

\author{
J. Hommeltenberg ${ }^{1,2}$, H. P. Schmid ${ }^{1,2}$, M. Drösler ${ }^{3}$, and P. Werle ${ }^{1}$ \\ ${ }^{1}$ Karlsruhe Institute of Technology KIT, Institute of Meteorology and Climate Research IMK-IFU, Kreuzeckbahnstrasse 19, \\ 82467 Garmisch-Partenkirchen Germany \\ ${ }^{2}$ Technical University of Munich, Chair of Atmospheric Environmental Research, Hans-Carl-von-Carlowitz-Platz 2/I, \\ 85354 Freising, Germany \\ ${ }^{3}$ University of Applied Sciences Weihenstephan-Triesdorf, Chair of Vegetation-Ecology, Weihenstephaner Berg 4, \\ 85354 Freising, Germany
}

Correspondence to: J. Hommeltenberg (janina.hommeltenberg@kit.edu)

Received: 19 December 2013 - Published in Biogeosciences Discuss.: 7 February 2014

Revised: 22 April 2014 - Accepted: 6 May 2014 - Published: 2 July 2014

\begin{abstract}
This study compares the $\mathrm{CO}_{2}$ exchange of a natural bog forest, and of a bog drained for forestry in the pre-Alpine region of southern Germany. The sites are separated by only $10 \mathrm{~km}$, they share the same soil formation history and are exposed to the same climate and weather conditions. In contrast, they differ in land use history: at the Schechenfilz site a natural bog-pine forest (Pinus mugo ssp. rotundata) grows on an undisturbed, about $5 \mathrm{~m}$ thick peat layer; at Mooseurach a planted spruce forest (Picea abies) grows on drained and degraded peat $(3.4 \mathrm{~m})$. The net ecosystem exchange of $\mathrm{CO}_{2}(\mathrm{NEE})$ at both sites has been investigated for 2 years (July 2010-June 2012), using the eddy covariance technique. Our results indicate that the drained, forested bog at Mooseurach is a much stronger carbon dioxide sink $\left(-130 \pm 31\right.$ and $-300 \pm 66 \mathrm{~g} \mathrm{C} \mathrm{m}^{-2} \mathrm{a}^{-1}$ in the first and second year, respectively) than the natural bog forest at Schechenfilz $\left(-53 \pm 28\right.$ and $\left.-73 \pm 38 \mathrm{~g} \mathrm{C} \mathrm{m}^{-2} \mathrm{a}^{-1}\right)$. The strong net $\mathrm{CO}_{2}$ uptake can be explained by the high gross primary productivity of the 44-year old spruces that overcompensates the two-times stronger ecosystem respiration at the drained site. The larger productivity of the spruces can be clearly attributed to the larger plant area index (PAI) of the spruce site. However, even though current flux measurements indicate strong $\mathrm{CO}_{2}$ uptake of the drained spruce forest, the site is a strong net $\mathrm{CO}_{2}$ source when the whole lifecycle since forest planting is considered. It is important to access this result in terms of the long-term biome balance. To do so, we used historical data to estimate the difference be-
\end{abstract}

tween carbon fixation by the spruces and the carbon loss from the peat due to drainage since forest planting. This rough estimate indicates a strong carbon release of $+134 \mathrm{t} \mathrm{Cha}^{-1}$ within the last 44 years. Thus, the spruces would need to grow for another 100 years at about the current rate, to compensate the potential peat loss of the former years. In contrast, the natural bog-pine ecosystem has likely been a small but stable carbon sink for decades, which our results suggest is very robust regarding short-term changes of environmental factors.

\section{Introduction}

On a global scale peatlands play a major role with respect to carbon exchange, even though they cover only $2.6 \%$ $\left(3.81 \times 10^{6} \mathrm{~km}^{2}\right)$ of Earth's land-surface area, with $80 \%$ of the peatland area found in temperate-cold climates of the northern hemisphere (Rydin and Jeglum, 2013). It has been estimated that northern peatlands have accumulated between 270 and $455 \mathrm{Pg}$ of carbon (Gorham, 1991; Turunen et al., 2002) since the last ice age (i.e., over the last $10^{4}$ years). This corresponds to $20-30 \%$ of the world's estimated soil carbon pool (Gorham, 1991) and $50 \%$ of atmospheric carbon (Houghton et. al., 1990). Furthermore, an annual carbon accumulation of $15-30 \mathrm{~g} \mathrm{C} \mathrm{m}^{-2} \mathrm{a}^{-1}$ in boreal peatlands has been estimated by Tolonen and Turunen (1996). It is generally accepted that undisturbed peatlands are the only 
terrestrial ecosystems that accumulate carbon continuously and over long timescales (Clymo, 1984). The importance of peatlands for the global carbon balance has been established by numerous studies carried out in the last 15 years (e.g., Erwin, 2009; Frolking and Roulet, 2007; Hargreaves et al., 2003; Moore et al., 1998). However, this carbon storage pool is threatened as many natural peatlands that are disturbed by human interference, for example, by peat cutting and land use change for agricultural use (Alm et al., 1999a; Drösler et al., 2008). In addition, the carbon storage potential of peatlands is threatened by climate-change-induced drought, as lower water tables lead to marked carbon emissions in peatland ecosystems (e.g., Alm et al., 1999b; Arneth et al., 2002; Aurela et al., 2007).

If peatlands are drained, such that the peat layer is no longer waterlogged, they lose their carbon accumulation capability. The organic soil carbon of the drained peat is oxidized to $\mathrm{CO}_{2}$ and emitted to the atmosphere. To date, a number of studies have investigated the $\mathrm{CO}_{2}$ exchange of peatlands and the environmental factors that control it by eddy covariance (e.g., Aurela et al., 2009; Lafleur et al., 2005; Sottocornola and Kiely, 2005), or chamber measurements (e.g., Bubier et al., 2003a; Goulden and Crill, 1997). The resulting carbon budgets depend on land use and peatland type. Generally, ombrotrophic bogs are stronger carbon sinks than more nutrient-rich fens (Byrne et. al., 2004), while intensive land use (e.g., cropland) leads to stronger $\mathrm{CO}_{2}$ emissions than extensive land use (Byrne et. al., 2004; Drösler et al., 2008). Most studies have focused on the greenhouse gas exchange of natural and agriculturally used peatlands (e.g., Alm et al., 1999a; Aurela et al., 2009; Aurela et al., 2007; Bubier et al., 2003b; Hendriks et al., 2007; Lafleur et al., 2003; Sottocornola and Kiely, 2005). However, studies about peatland forests are still rare; e.g., Maljanen et al. (2010) emphasize the lack of knowledge about the carbon budget of peatland forests, even in the boreal climate zone.

So far, there is no agreement whether peatland drainage for forestry generally leads to net gain or net loss of carbon. A number of studies about the long-term net carbon exchange of drained peatland forests has been carried out in Great Britain and Scandinavia. Most of them are based on extrapolated chamber measurements and model approaches. These studies found that the loss of peat carbon is mainly compensated by the carbon fixation of the trees (e.g., Hargreaves et al., 2003; Minkkinen et al., 2002; Ojanen et al., 2013). However, Armentano and Menges (1986) noted that in temperate regions, regional mean losses of soil carbon are about 10 times larger than in boreal regions. Cannell et al. (1993) concluded that carbon losses larger than $+300 \mathrm{~g} \mathrm{C} \mathrm{m}^{-2} \mathrm{a}^{-1}$ cannot be compensated by the carbon uptake of the trees in drained and afforested peatlands in Britain, and that peatland afforestation may lead to net loss of carbon.

Some short-term studies conclude that peatland ecosystems drained for forestry are net $\mathrm{CO}_{2}$ sinks (Lohila et al., 2011; Meyer et al., 2013; von Arnold et al., 2005). How- ever, eddy covariance measurements over a boreal drained forest in central Sweden show considerable net $\mathrm{CO}_{2}$ loss over 2 measurement years (Lindroth et al., 1998), while other studies determined net $\mathrm{CO}_{2}$ exchange close to zero (Dunn et al., 2007; Lohila et al., 2007). The results of these studies are fraught by large uncertainties, and most are based on measurements that were extremely extrapolated in time and space. Furthermore, the reported carbon budgets are difficult to compare, because the carbon balances were determined by several different approaches (e.g., eddy covariance method, chamber measurements, and biometric estimates of carbon stock changes). In addition, studied peatland sites were highly variable in terms of their nutrient supply, drainage system, tree population, and their climate conditions (e.g., temperatures, precipitation, and snow coverage), all of which affect the cycling of carbon through these ecosystems.

The objective of this study is to compare the $\mathrm{CO}_{2}$ budget of a natural and a drained peatland forest in the pre-Alpine region of southern Germany. The key issue to be addressed centers on the magnitude of the $\mathrm{CO}_{2}$ budgets at these sites and the critical factors that account for the differences between them. To our knowledge this is the first direct comparison of the $\mathrm{CO}_{2}$ exchange between natural and managed peatland forests in the temperate climate zone. Methane is likely also important for full greenhouse gas estimates in peatland ecosystems. Unfortunately, methane fluxes are not available for both sites, and thus we cannot compare these two sites in terms of their global warming potential.

\section{Materials and methods}

We report on $\mathrm{CO}_{2}$ exchange measurements made over 2 years with the eddy covariance technique, from 1 July 2010 to 30 June 2012.

\subsection{Site description}

Measurements took place at two bog forests located within the pre-Alpine region of southern Germany (Fig. 1), approximately $40 \mathrm{~km}$ south of Munich (Fig. 1c): Mooseurach (drained): $47^{\circ} 48^{\prime} 34 \mathrm{~N}, 11^{\circ} 27^{\prime} 28 \mathrm{E}, 598 \mathrm{~m}$ a.s.l. and Schechenfilz (natural): $47^{\circ} 48^{\prime} 23 \mathrm{~N} ; 11^{\circ} 19^{\prime} 39 \mathrm{E}, 590 \mathrm{~m}$ a.s.l. The sites are separated by $10 \mathrm{~km}$, thus sharing the same glacial history and weather conditions. The lakes and peatlands in this pre-Alpine region including both sites were formed on the basal moraine after the retreat of the Isar piedmont glacier (Isar-Vorlandgletscher) at the end of the last ice age. Peatlands in this region extend over the lowlands, an area south of lakes Ammer and Starnberg that reaches far beyond the two present study sites (Fig. 1c). The climate can be characterized as cool-temperate and humid with an average annual temperature of $8.6^{\circ} \mathrm{C}$ and an average annual precipitation of $1127 \mathrm{~mm}$ (Table 1). The maximum precipitation 


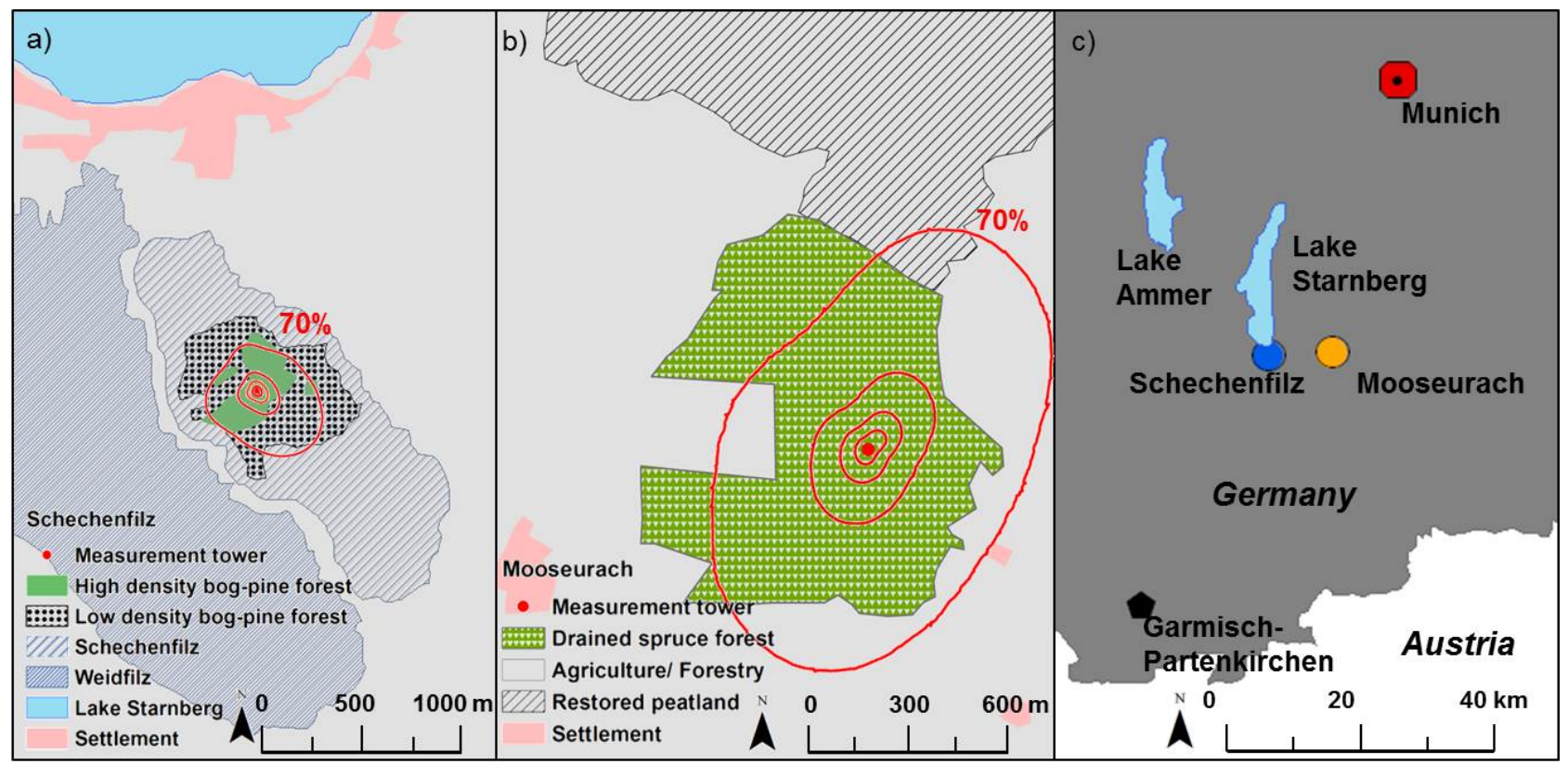

Figure 1. (a) Schematic map of the Schechenfilz site (grey, line-filled area). The target area is the bog-pine forest (high and low density), (b) Schematic map of the Mooseurach site (the target area is marked with green triangles). Red lines indicate the isolines (10, 30, 50 and 70\%) of the mean flux footprint area of the year 2011; (c) Location of the research sites in southern Bavaria, Germany. All maps are in a different scale.

Table 1. Long-term yearly averages of meteorological parameters (sum of precipitation, mean of air temperature $\left(T_{\text {air }}\right)$, mean relative humidity (RH) and the sum of sunshine duration), provided by the nearby (distance of 8.5 and $10.5 \mathrm{~km}$ to the natural site Schechenfilz and to the drained site Mooseurach, respectively) weather station Attenkam, run by the German Weather Service (DWD). Long-term sunshine duration is provided by the weather station Hohenpeißenberg (distance of 24 and $34 \mathrm{~km}$ ).

\begin{tabular}{lcccc}
\hline Period & $\begin{array}{c}\text { Precipi- } \\
\text { tation } \\
\mathrm{mm} \mathrm{a}^{-1}\end{array}$ & $\begin{array}{c}T_{\text {air }} \\
{ }^{\circ} \mathrm{C}\end{array}$ & $\begin{array}{c}\text { RH } \\
\%\end{array}$ & $\begin{array}{c}\text { Sunshine } \\
\text { hours } \\
\mathrm{h}\end{array}$ \\
\hline $1971-2011$ & 1127 & 8.6 & 77.9 & 1817 \\
\hline 2010 & 1209 & 7.6 & 80.1 & 1645 \\
2011 & 1092 & 9.6 & 78.4 & 2114 \\
2012 & 1141 & 8.7 & 80.2 & 1902 \\
\hline
\end{tabular}

occurs during the summer months $(40 \%)$. While the general atmospheric conditions are the same, the sites are clearly distinct by their land use history.

\subsubsection{Schechenfilz (natural)}

The near-natural ombrotrophic bog Schechenfilz (111 ha) (Fig. 1a) is part of the conservation area Osterseen. The northern part of the bog complex Schechenfilz was affected by peat cutting until the 1950s and was restored in 2001 . However, in the present observation area, located in the cen- ter of the bog complex, the peat layer is still pristine. This vegetation is structured in open sedge, heather meadows and wooded areas. The study site is situated in a wooded area, dominated by slow growing bog-pines (Pinus mugo ssp. rotundata Link) that reach an average height of $2 \mathrm{~m}$. The age of the trees varies from sapling up to 150 years. The average plant area index (PAI) of the bog pines is $2.3 \pm 0.8$. The ground layer vegetation is dominantly formed by peat mosses (Sphagnum spp.) in addition to heather (Calluna vulgaris L.), bog bilberry scrubs (Vaccinium uliginosum L.s.l.) and several species of the sedge-family (Cyperaceae, mainly Eriophorum vaginatum $\mathrm{L}$., hare's-tail cottongrass). As in all such bog forests, the distribution of vegetation is quite heterogeneous, but the heterogeneity occurs at scales much smaller than the expected flux measurement footprint (see also Sect. 2.3).

The analyses of a soil profile indicate pristine peat conditions at this site (N. Rosskopf, personal communication, 2012, Fig. 2). The upper $12 \mathrm{~cm}$ are only temporarily watersaturated, and plants are only very weakly decomposed so that their structure is easily discernible. The underlying continuously water-saturated layer extends to a thickness of almost $5 \mathrm{~m}$ (from 0.12 to $5.10 \mathrm{~m}$ below surface level). Physical and chemical analyses of a soil profile show a high carbon content of about $50 \%$ and $\mathrm{pH}$ values of about 4 , indicating the acid environment typical for peat bogs. The $\mathrm{C} / \mathrm{N}$ ratio $(45 \pm 13)$ varies within the different layers but shows a consistently low nutrient supply. Peat conditions as well as vegetation composition correspond to typical pristine bog 


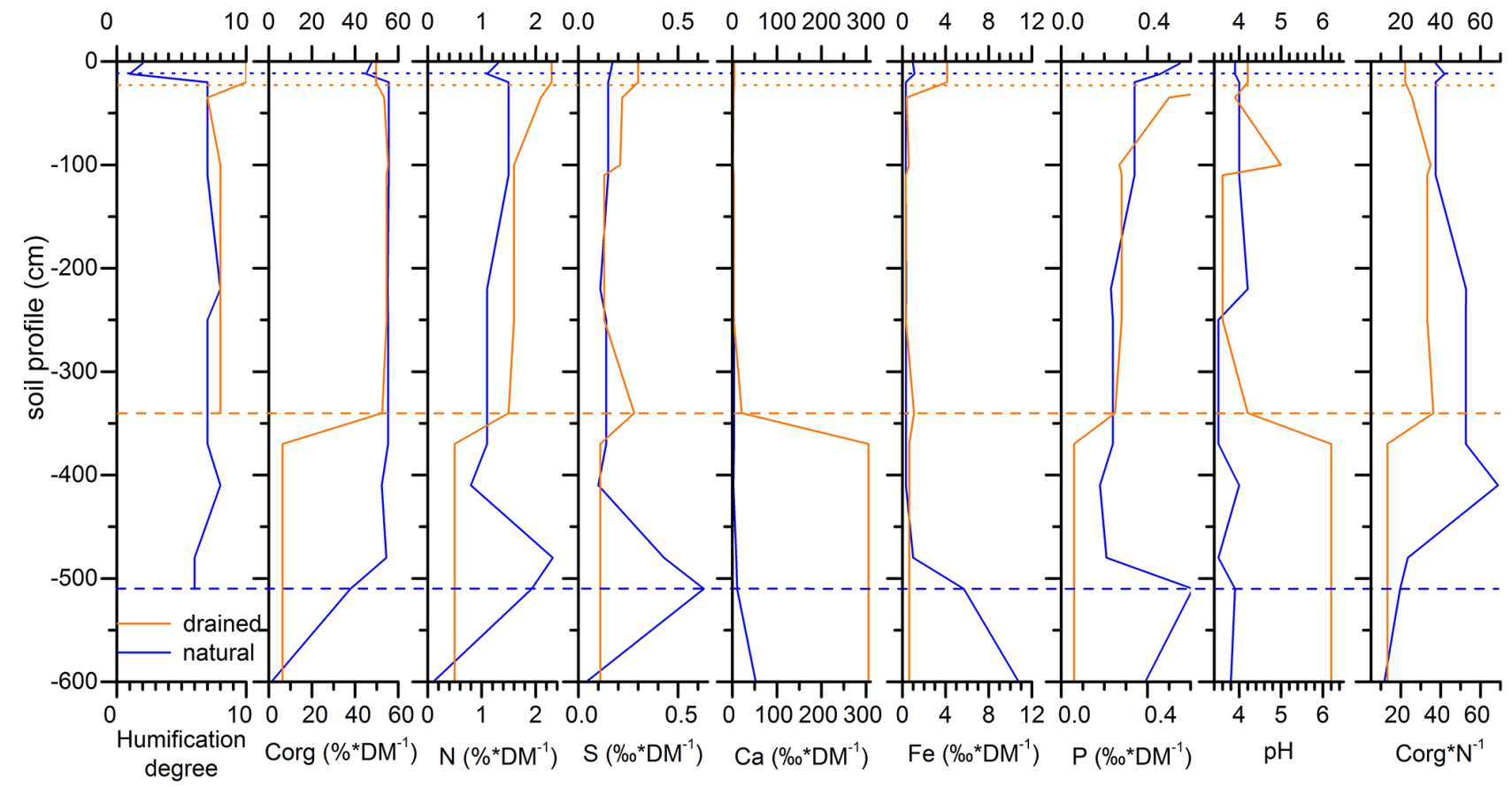

Figure 2. Soil characteristics and element concentrations of the different peat layers at the natural and the drained sites (Corg: organic carbon, N: nitrogen, S: sulfur, Ca: calcium, Fe: iron, P: phosphorus, DM: dry matter). Dotted lines indicate threshold between frequently water-saturated layer and permanent water-saturated layer. Dashed lines indicate threshold between peat and mineral soil layer. Data are provided by the analysis of one soil profile at each site.

characteristics, so we consider the site at Schechenfilz to be a natural bog forest.

The wind direction at this site is mostly influenced by the lake breeze phenomena induced by Lake Starnberg in the north of the research site (Fig. 1a). The prevailing wind direction varies mostly between $340^{\circ}$ and $350^{\circ}$ at daytime, and is around $135^{\circ}$ at night.

\subsubsection{Mooseurach (drained)}

The Mooseurach site (70 ha) is part of a large bog complex ( 250 ha, Fig. 1b) that was drained at the beginning of the 20th century. Initially, the research area was used for agriculture. However, due to unfavorable agricultural site conditions, such as nutrient deficiency and a still relatively high water table, agricultural use was discontinued after only a few years. The area was used as grassland and pastureland for about 2 to 3 decades. In the 1960s forestry became more important. The research area was afforested in 1967; the dominant species is Norway spruce (Picea abies L. Karst with additions of Scots pine (Pinus sylvestris L.). Presently, the 44year old spruce forest has an average canopy height of $21 \mathrm{~m}$, a stem density of between 500 and 600 stems ha $^{-1}$ and an average PAI of $5.9 \pm 2.0$. The peat is moderately drained, and although the drainage system is no longer maintained, it is still effective. Analyses of the soil at Mooseurach (N. Rosskopf, personal communication, 2012; Fig. 2) demonstrate the ef- fects of drainage: in the upper $20 \mathrm{~cm}$, humification of the peat is well advanced and plant structures are no longer identifiable (humification degree 10 out of 10 after von Post, 1922). Between 20 and $35 \mathrm{~cm}$ beneath the surface the peat is occasionally water-saturated in the course of the year, and below this is an almost $3 \mathrm{~m}$ thick continuously water-saturated peat layer. Below $3.4 \mathrm{~m}$ the soil material is mineral. It should be noted that the fraction of available nitrogen $(\mathrm{N})$ is greater due to drainage, implying a better availability of nutrients which is supported by the lower $\mathrm{C} / \mathrm{N}$ ratio ( $33.5 \pm 5.5$, Fig. 2). The drained site is also characterized by stronger humification and mineralization of the peat.

Based on a $75 \mathrm{~m}$ gridded stratigraphic survey of peat thickness (including about 70 measurements in the target area; Fig. 1) from the end of the 1930s (data courtesy of the District Government of Upper Bavaria), the former peat thickness at the location of the current soil measurements was $4.4 \mathrm{~m}$. This is about $1 \mathrm{~m}$ thicker than today, illustrating the peat loss in the last 70-80 years.

At Mooseurach, the prevailing wind direction is southwesterly. In addition, winds from northeastern directions occur frequently.

\subsection{Instrumentation}

$\mathrm{CO}_{2}$ exchange was measured at the two study sites using the eddy covariance technique (e.g., Baldocchi et al., 1988; 
Foken et al., 2012). Due to differences in vegetation height, a $30 \mathrm{~m}$ radio-antenna-type tower was installed at the $21 \mathrm{~m}$ high drained spruce forest at Mooseurach and a $6 \mathrm{~m}$ tower in the bog-pine forest (canopy height about $2 \mathrm{~m}$ ) at Schechenfilz. The towers were equipped with eddy covariance systems complemented by instruments to measure relevant auxiliary parameters. A 3-D sonic anemometer (CSAT-3, Campbell Scientific, Inc., Logan, Utah, USA) was used at each site and mounted almost at the top of the tower. The aerodynamic measurement height is $4.34 \mathrm{~m}$ about the zero-plain displacement level at the natural bog-pine site and $15.6 \mathrm{~m}$ at the drained spruce forest. Carbon dioxide and water vapor were measured at the natural site by an open-path infrared gas analyzer (IRGA, LI7500, Li-Cor, Inc., Lincoln, Nebraska, USA), while at the drained site a closed-path infrared gas analyzer (LI7200, Li-Cor) was installed. The intake tube was a $1 \mathrm{~m}$ insulated steel line with $3 / 8$ in. inner diameter and a flow rate of $15 \mathrm{~L} \mathrm{~min}^{-1}$. The measurement principle of LI7200 is based on the absolute non-dispersiveinfrared (NDIR) design of the LI7500 (Burba et al., 2010), which leads to a good agreement between the two measurement devices. The closed path system has a considerable advantage, because rain drops and fog do not compromise the measurements of the closed-path system, which leads to higher data coverage (see Sect. 2.3).

At the top of each tower, air temperature and relative humidity were measured by the HMP45C (Vaisala, Helsinki, Finland), photosynthetic active photon flux density (PPFD) by the LI 190SL (Li-Cor), the net radiation by the heated and ventilated CNR4 (Kipp and Zonen, Delft, the Netherlands). Precipitation was detected by a heated tipping bucket rain gauge 52202 (Campbell Scientific) mounted about $1 \mathrm{~m}$ above the canopy at each site. Groundwater table fluctuations were measured continuously by several mini-diver gauges (Schlumberger Water Services, Delft, the Netherlands; eight gauges at the natural site and four at the drained site), distributed over the core of the bog, including the footprint area. The water content was detected by three water content reflectometers CS616 (Campbell Scientific), averaging the water content of the first $30 \mathrm{~cm}$. For measurements of volumetric water content in organic soils the calibration coefficients of the measurement devices have to be adapted. We adopted the coefficients according to Yoshikawa et al. (2004) for organic soils consisting of dead sphagnum material. The surface temperature was measured by an infrared remote sensor IR100 (Campbell Scientific). The PAI of the trees is the mean of 100 individual measurements with the SunScan Canopy Analysis System SS1 (Delta-T, Cambridge, UK). At the natural site the soil temperature at $0.1 \mathrm{~m}$ depth was measured by thermistor temperature probes (type T107,Campbell Scientific) and at the drained site by soil temperature profiles STP01SC (Hukseflux, Delft, the Netherlands) at five different depths $(0.02,0.05,0.1,0.2,0.5 \mathrm{~m})$.

\subsection{Data handling}

The calculation and correction of the turbulent half-hourly $\mathrm{CO}_{2}$ fluxes were performed with the software package TK3 (Mauder and Foken, 2011) that includes adjustments accounting for density fluctuations for the open-path flux measurements (WPL-adjustment after Webb et al., 1980) and spectral loss (high frequency) following Moore (1986). Furthermore, we applied the planar fit method after Wilczak et al. (2001). One regression plain was determined semiannually to ensure zero mean vertical wind speed for this time period.

Eddy covariance measurements allow the detection of continuous time series although data gaps occur for various reasons. Short gaps occurred sporadically, due to sensor malfunction, in particular of the open path $\mathrm{CO}_{2} / \mathrm{H}_{2} \mathrm{O}$ analyzer during wet and foggy conditions. At the drained site Mooseurach, four long data gaps occurred for the periods of 12-19 April 2011, 10-25 July 2011, 15-26 November 2011 and 23 February-27 March 2012. At the natural site Schechenfilz three long gaps happened for the periods 23-26 October 2010, 28 April-04 May 2011 and 22-27 May 2011. These longer data gaps were caused by power failure or problems of data storage. The raw data coverage of half-hourly flux measurements was $91 \%$ at the drained site and $72 \%$ at the natural site. Subsequently, these data were screened to ensure good quality according to three rejection criteria.

First we applied an analytical footprint model (Kormann and Meixner, 2001) to estimate how well the measured fluxes captured the sources and sinks of the bog forest. If more than $70 \%$ of the 30 min flux footprint overlapped with the area of interest, the data were used for further analysis; otherwise the data were rejected. At the drained spruce forest $21 \%$ of the flux measurements did not originate from the area of interest (about 70 ha). At the natural site the target area (marked as high- and low-density bog-pine forest in Fig. 1a) is large (about $25 \mathrm{~h}$ ) relative to the lower measurement height, and thus the footprint size matches the area of interest. It was therefore not necessary to apply a footprint criterion at the natural bog-pine site.

Second, an important source of error in the calculation of NEE is the underestimation of nighttime fluxes, due to low turbulence conditions. During such situations, emitted $\mathrm{CO}_{2}$ can accumulate near the surface and be advected away from the ecosystem without reaching the measurement system. Following standard practice (e.g., Aubinet et al., 2012; Goulden et al., 1996; Schmid et al., 2003), the friction velocity $\left(u_{*}\right)$ was used to determine time periods when flux measurements were likely to be unreliable as a result of limited atmospheric mixing. The limiting value of friction velocity that indicates sufficient turbulence depends on surface roughness and therefore on vegetation type. We determined lower $u_{*}$ limits of 0.225 and $0.125 \mathrm{~m} \mathrm{~s}^{-1}$ at the drained site Mooseurach and the natural site Schechenfilz, respectively, following the method of Goulden et al. (1996). Above these 
thresholds the flux measurements no longer showed a dependence on friction velocity. Based on this criterion $30 \%$ of all data had to be rejected at each of the sites, particularly at night.

Finally, an outlier test was applied to filter out unrealistic singular values. We separated the dataset into daytime ( $>20 \mathrm{~W} \mathrm{~m}^{-2}$ global radiation) and nighttime values $\left(<20 \mathrm{~W} \mathrm{~m}^{-2}\right.$ global radiation) and used a moving window with a width of \pm 14 half-hourly values. For each moving window we calculated the average and the $99 \%$ confidence interval of this average. Each $30 \mathrm{~min}$ flux value within the window had to be within the $99 \%$ confidence interval, otherwise the value was excluded from further calculations. This conservative outlier test rejected only $1 \%$ of the data at the drained site and $2 \%$ at the natural site. Considering missing values (28 and 9\% the natural and the drained site, respectively) and data rejection based on strict criteria (32 and $52 \%$ ) leads to a high quality data set covering about $40 \%$ of the entire measurement period. An overview on missing and rejected data is given in Table 2.

\subsection{Gap-filling method}

The net ecosystem exchange of $\mathrm{CO}_{2}$ (NEE) is the sum of two components driven by nearly independent processes that cause fluxes of approximately the same magnitude, but opposite directions (Moncrieff et al., 1996): the upward directed ecosystem respiration $\left(R_{\text {eco }}\right)$ and the downward directed gross primary production (GPP). Therefore, a negative NEE indicates dominant $\mathrm{CO}_{2}$ uptake and a positive NEE dominant $\mathrm{CO}_{2}$ release by the ecosystem.

In order to enable an analysis of the seasonal patterns of NEE or differences in the $\mathrm{CO}_{2}$ balance between the sites, a gap-filling strategy was required to replace the missing data. We used a non-linear regression method according to Falge et al. (2001) and Moffat et al. (2007) to model the GPP and $R_{\text {eco }}$ components individually.

The respiration model is based on an Arrhenius-type exponential relation between nighttime $\mathrm{CO}_{2}$ fluxes and temperature. Nighttime data were identified using a global radiation threshold of $20 \mathrm{~W} \mathrm{~m}^{-2}$ (Reichstein et al., 2005), and the temperatures used were those that provided the best fit, and consequently the lowest uncertainty of gap-filling, at each site. The temperatures thus selected were the soil temperature at a depth of $0.1 \mathrm{~m}$ at the natural bog-pine forest and the surface temperature at the drained spruce forest. The relation used is based on an empirical equation of Lloyd and Taylor (1994):

$R_{\text {eco,night }}=R_{\text {ref }} \times \exp \left[E_{0}\left(\frac{1}{T_{\text {ref }-T_{0}}}-\frac{1}{T-T_{0}}\right)\right]$,

where $R_{\text {ref }}$ is defined as the ecosystem respiration at a reference temperature of $283.15 \mathrm{~K}$ ( $\left.T_{\text {ref }}\right), E_{0}$ is a fitting parameter called the activation energy in $K, T_{0}$ is a constant temperature of $227.13 \mathrm{~K}$ and $T(\mathrm{~K})$ the measured half-hourly temperatures providing the best fit. To ensure realistic relationships
Table 2. Reasons for data loss and their percentage for both sites.

\begin{tabular}{lcc}
\hline $\begin{array}{l}\text { Data loss } \\
\text { due to: }\end{array}$ & $\begin{array}{c}\text { Schechenfilz } \\
\text { natural } \\
\text { percentage } \\
(\%)\end{array}$ & $\begin{array}{c}\text { Mooseurach } \\
\text { drained } \\
\text { percentage } \\
(\%)\end{array}$ \\
\hline $\begin{array}{l}\text { Maintenance, power failure, } \\
\text { sensor failure }\end{array}$ & 28 & 9 \\
Footprint outside target area & - & 21 \\
\hline $\begin{array}{l}\text { Insufficient turbulence } \\
\text { Declared as outliers }\end{array}$ & 30 & 30 \\
\hline Remaining data & 2 & 1 \\
\hline
\end{tabular}

we fitted the data over a wide temperature range choosing a fitting period of 6 months. As the respiration-temperature relationship showed no response to the phenology of the vegetation the fitting period is taken to be of acceptable length.

During the daytime (global radiation $>20 \mathrm{~W} \mathrm{~m}^{-2}$ ), the respiration $\left(R_{\text {eco, day }}\right)$ was estimated by the same fitting parameters, determined by the nighttime respirationtemperature-relation (Eq. 1). Note that here $R_{\text {eco, day }}$ indicates ecosystem respiration determined by the nighttime relation, but using daytime temperature only. The GPP was modeled with a rectangular hyperbolic Michaelis-Menten-type function (Falge et al., 2001):

$\mathrm{NEE}=\frac{\alpha^{\prime} \times \mathrm{PPFD} \times \mathrm{GPP}_{\max }}{\left(\mathrm{GPP}_{\max }+\alpha^{\prime} \times \mathrm{PPFD}\right)}+R_{\mathrm{eco}}$,

where $\alpha^{\prime}$ is the apparent quantum yield, interpreted as the ecosystem light use efficiency $\left(\mu \mathrm{mol} \mathrm{m}{ }^{-2} \mathrm{~s}^{-1} / \mu \mathrm{mol} \mathrm{m} \mathrm{m}^{-2} \mathrm{~s}^{-1}\right)$. In this case the carbon uptake per photon PPFD. The fitting parameter GPP max $_{\text {ax }}$ is the maximum carbon fixation rate at unlimited PPFD. The annual growing cycle of vegetation activity is strongly related to radiation and temperature variation. Based on this scheme, GPP was calculated for 13 different periods, whose lengths depended on the mean daily soil temperature at $0.1 \mathrm{~m}$ depth. During transition periods in spring and autumn we used a temperature range of $2^{\circ} \mathrm{C}$, and during more stable periods in midsummer and winter $4^{\circ} \mathrm{C}$. For the estimate of uncertainty please refer to the Appendix.

\section{Results and discussion}

\subsection{Meteorological site characteristics during the measurement period}

As expected, atmospheric parameters, such as global radiation and precipitation, were essentially the same at the two sites. The coefficients of determination $\left(R^{2}\right)$ of the linear regressions of half-hourly meteorological values at the sites 
indicate a correlation better than 0.97 , the slopes of the linear fits are close to 1 and the offsets are almost zero.

However, site-related environmental factors such as soil temperature and water table depth (WTD) were different (Fig. 3c-e). Following Couwenberg's classification (2011), the natural bog Schechenfilz belongs to the class of wet peatlands, where the mean annual water table depth during the 2 years measurement period is above $-0.2 \mathrm{~m}$ $(-0.06 \pm 0.04 \mathrm{~m})$. At the drained bog Mooseurach, the mean annual water table is just below $-0.2 \mathrm{~m}(-0.21 \pm 0.08 \mathrm{~m})$, thus making Mooseurach a dry peatland site. The water table was consistently higher at the natural site; in addition, water content was more stable than at the drained bog Mooseurach. Due to its intact drainage system, the water table at Mooseurach reacted more rapidly to low-precipitation periods. The water holding capacity of the pristine soil is much larger than that of the drained soil (Fig. 3d, e).

Overall, the first measurement period was slightly cooler and wetter than the second measurement period. Within the 2 years, five periods of considerable water table drawdown were recorded, more prominently at the drained ecosystem (Fig. 3e): at the beginning of July 2010, during the warm and sunny spring of 2011, during the warm and relatively dry period in August and September 2011, and in November 2011 when there was no precipitation and it was sunny (more than $50 \%$ longer sunshine duration in November 2011 (142 h) compared to the long-term (92h)) but about $1{ }^{\circ} \mathrm{C}$ cooler than the long-term average. The period in November led to the strongest water table drawdown (average water table in November 2011: $-0.37 \mathrm{~cm}$ below the surface) at the drained site. Another strong water table drawdown was recorded during the extraordinary cold period in January and February 2012. At this time, the monthly air temperature was about $-4{ }^{\circ} \mathrm{C}$ lower than the long-term average and we measured half-hourly temperature extremes of below $-20^{\circ} \mathrm{C}$. Unfortunately, temperatures were below the operation range of the gauges, hence the extent of the detected strong water table drawdown in February 2012 remains uncertain and will not be considered in further discussions.

\subsection{Factors affecting $\mathrm{CO}_{2}$ exchange}

The individual component fluxes, $R_{\text {eco }}$ and GPP, which form the NEE, depend on different environmental factors that vary throughout the year.

GPP is mainly controlled by photosynthetic active photon flux density. As expected, we detected a strong hyperbolic relationship between GPP and PPFD (Fig. 4a) at both sites. Light use efficiency as well as maximum GPP (i.e., at infinite PPFD) was larger at Mooseurach (drained) than at Schechenfilz (natural), resulting in a two-times larger carbon uptake at the drained site. However, after normalizing the GPP with the corresponding PAI, such that GPP norm $=\mathrm{GPP} / \mathrm{PAI}$ (PAI was 5.9 at the drained site and 2.3 at the natural site), we found very similar light use efficiencies and almost equal GPP $_{\text {norm }}$
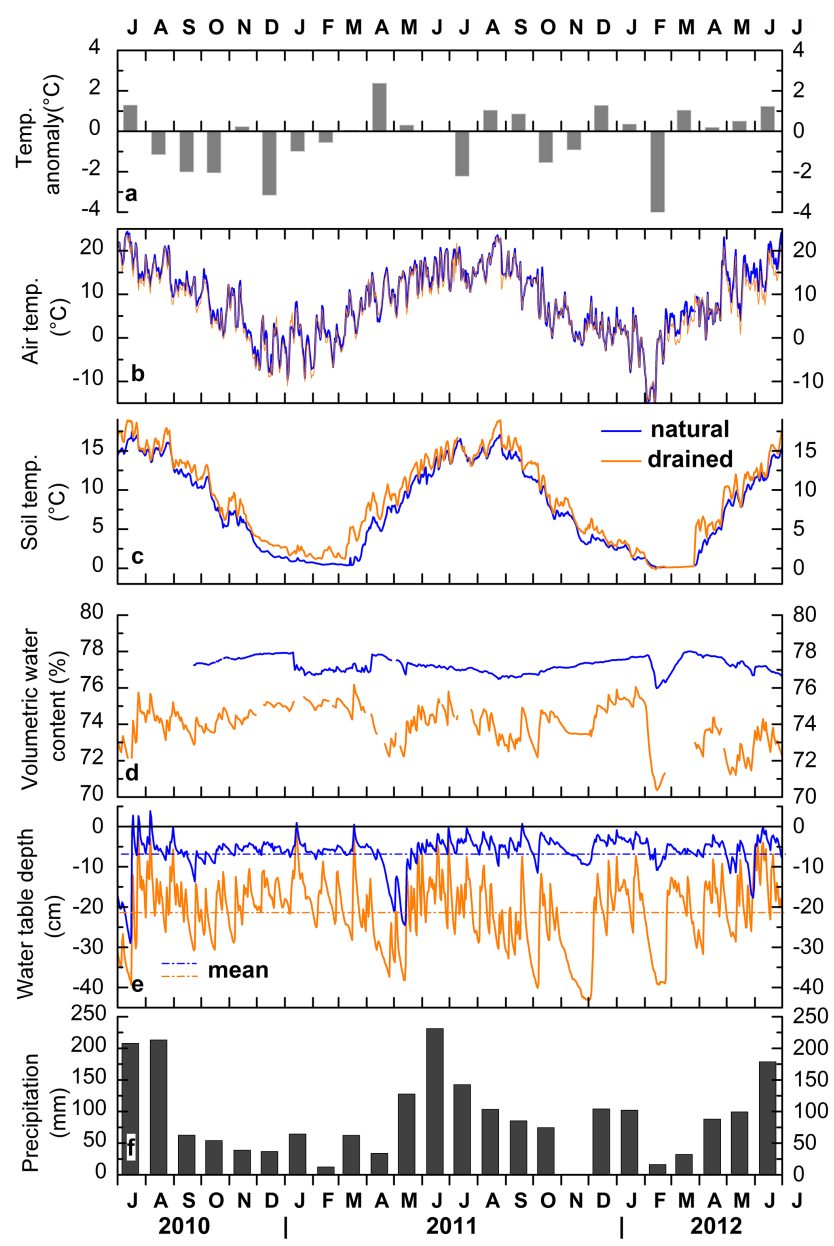

Figure 3. Time series of daily means $(\mathbf{b}, \mathbf{c}, \mathbf{d}, \mathbf{e})$ and monthly values $(\mathbf{a}, \mathbf{f})$ of environmental parameters from 1 July 2010 to 30 June 2012. The temperature anomaly is based on 40 years of long-term data, provided by the German weather service (DWD). The air temperatures were measured at 6 and $30 \mathrm{~m}$ height in Schechenfilz (natural) and in Mooseurach (drained), respectively. The presented soil temperatures were measured at $0.1 \mathrm{~m}$ depth. The volumetric water content is the average of the $30 \mathrm{~cm}$ upper peat layer. Over the 2 measurement years, the mean water table depth is $-0.21 \pm 0.08 \mathrm{~m}$ at the drained site and $-0.06 \pm 0.04 \mathrm{~m}$ at the natural site.

( -387 and $-434 \mathrm{~g} \mathrm{C} \mathrm{m}^{-2} \mathrm{a}^{-1}$ at the natural site and -305 and $-350 \mathrm{~g} \mathrm{C} \mathrm{m}^{-2} \mathrm{a}^{-1}$ at the drained forest, respectively) at both sites and for both analyzed periods, respectively. Note: $\mathrm{GPP}_{\text {norm }}$ has the same unit as PAI is dimensionless.

Respiration increases with increasing temperature (Fig. 4b). For the whole temperature range, respiration was greater at the drained forest than at the natural forest. At the reference temperature of $10^{\circ} \mathrm{C}$, the respiration of the drained ecosystem was about two-times larger. Following the notion that more biomass usually produces more respiration, we

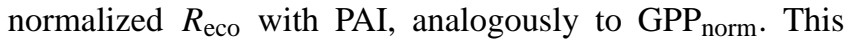
resulted in very similar normalized emission rates $\left(R_{\text {eco,norm }}\right.$ was +283 and $+299 \mathrm{~g} \mathrm{Cm}^{-2} \mathrm{a}^{-1}$ at the drained forest 

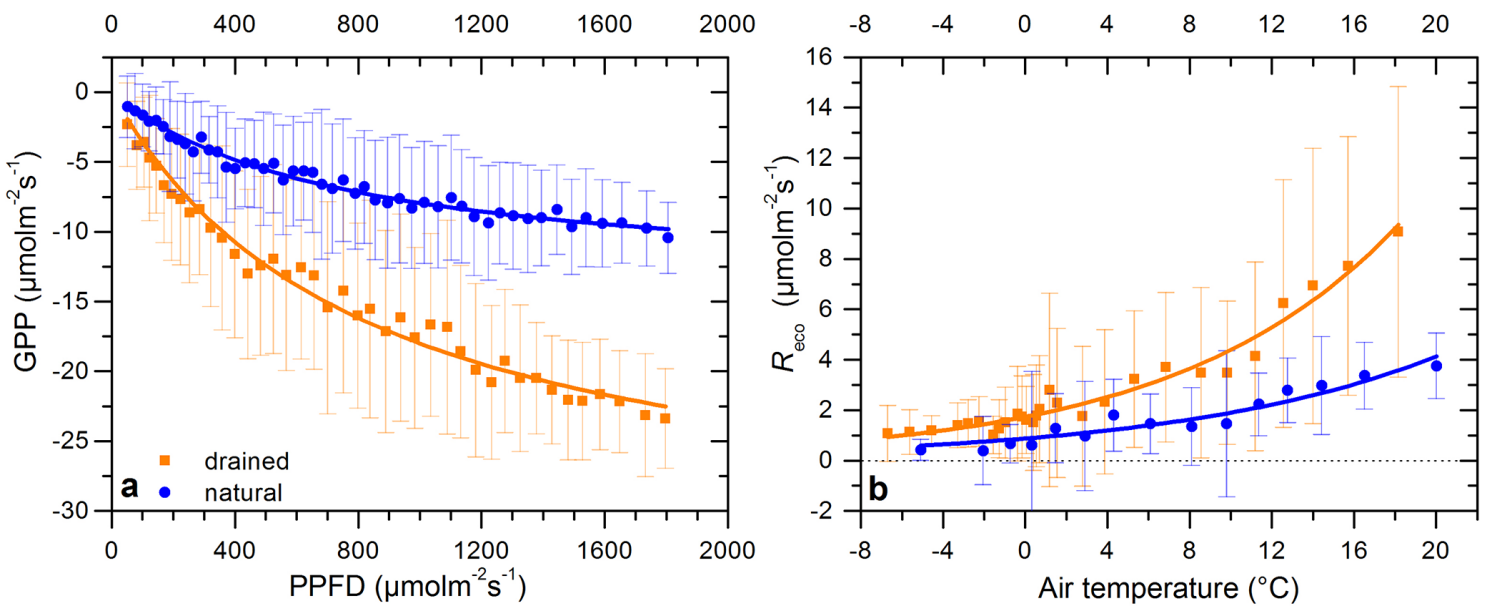

Figure 4. (a) GPP (daytime fluxes $-R_{\mathrm{eco}}$ ) versus PPFD; (b) ecosystem respiration $\left(R_{\mathrm{eco}}\right.$, nighttime fluxes) versus air temperature. Each point is the average of 100 non-gap-filled half-hourly measurements. The bars denote the standard deviations. Plots show binned data from the whole year 2011. Air temperature and PPFD were measured at the top of each tower ( $6 \mathrm{~m}$ at the natural site and $30 \mathrm{~m}$ at the drained site).

and +364 and $+403 \mathrm{~g} \mathrm{C} \mathrm{m}^{-2} \mathrm{a}^{-1}$ at the natural pine-bog, respectively) between the sites for both analyzed periods. Nevertheless, respiration processes are very complex and cannot be solely attributed to PAI.

We further tested for dependences between changes in volumetric water content (VWC) and nighttime respiration (Fig. 5) for the drained forest. The slope of $R_{\text {eco }}$ in Fig. 5a suggests a moderate exponential relation between $R_{\text {eco }}$ and volumetric water content. However, VWC is also linked to air temperature. After normalization of $R_{\text {eco }}$ with air temperature using the relations of Fig. $4 \mathrm{~b}$, to exclude the influence of air temperature on $R_{\text {eco }}$, the dependence between $R_{\text {eco }}$ and water content disappeared (Fig. 5c). The same applies to the data from the natural site. Differences in VWC resulted in marked differences in respiration at the two sites, but short-term fluctuations could be explained by the air temperature dependence. Because VWC and water table depth indicate similar variations (Fig. 3), a similar dependence between temperature, $R_{\text {eco }}$ and water table could be assumed.

\subsection{Annual $\mathrm{CO}_{2}$ exchange}

Annual budgets of NEE, GPP and $R_{\text {eco }}$ were calculated for the observation periods from July 2010 to June 2011 and July 2011 to June 2012. Despite similarities in weather conditions and geological origin, the carbon budgets of the drained and the natural peatland were considerably different. The individual budgets of GPP and $R_{\text {eco }}$ for the whole annual cycle show that respiration as well as GPP were approximately two-times larger at Mooseurach (drained) than at Schechenfilz (natural) (Fig. 6).

The NEE indicates stronger $\mathrm{CO}_{2}$ uptake at the drained site. At both sites the uptake was smaller in the first, slightly wetter and colder, measurement period from July 2010 to June $2011\left(-130 \pm 31 \mathrm{~g} \mathrm{C} \mathrm{m}^{-2} \mathrm{a}^{-1}\right.$ at the drained
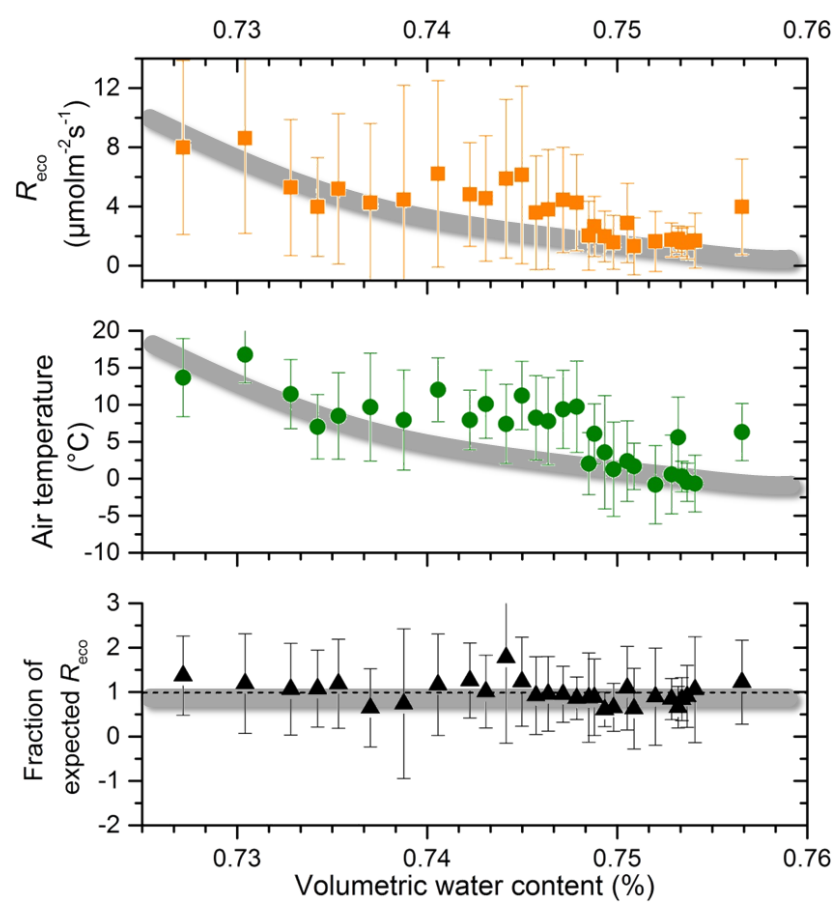

Figure 5. Relationship between VWC and $R_{\text {eco }}$ (non-gap-filled), air temperature and the fraction of expected $R_{\text {eco }}$ (measured $R_{\text {eco }} /$ modeled $R_{\text {eco }}$ by temperature relation). Each point is the average of 100 non-gap-filled half-hourly measurements. The vertical bars denote the standard deviations. The grey line represents an exponential dependence. Plots show binned data from 2011 at Mooseurach.

site and $-53 \pm 28 \mathrm{~g} \mathrm{Cm}^{-2} \mathrm{a}^{-1}$ at the natural site; see the Appendix for methods to determine uncertainty) than in the second measurement period from July 2011 to June $2012\left(-300 \pm 66 \mathrm{~g} \mathrm{C} \mathrm{m}^{-2} \mathrm{a}^{-1}\right.$ at the drained site and 


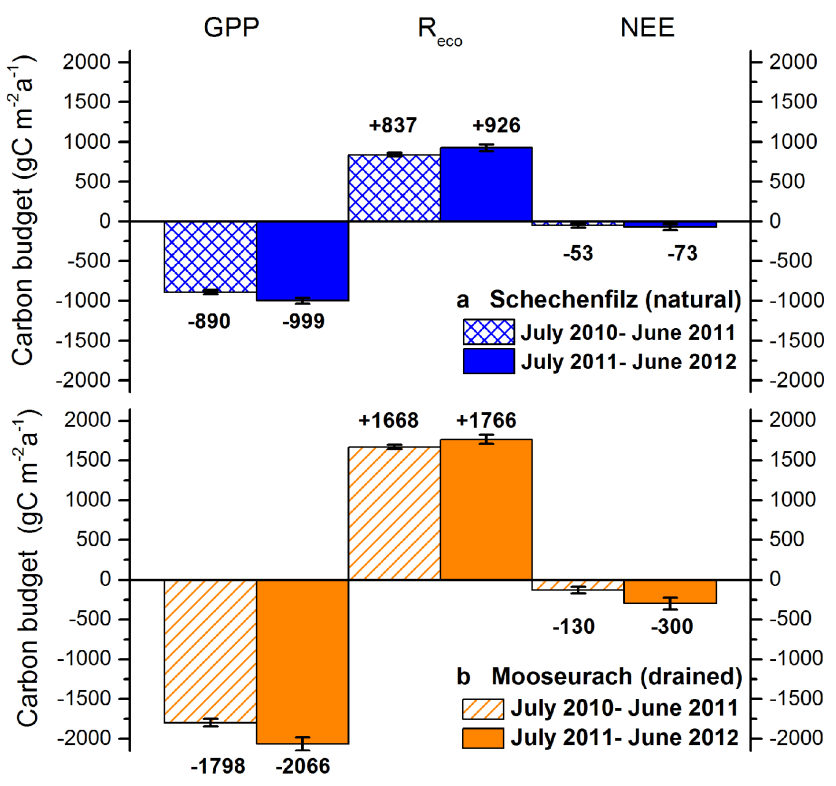

Figure 6. Annual sums of NEE, $R_{\mathrm{eco}}$ and GPP at (a) the natural site Schechenfilz and (b) the drained site Mooseurach for the two measurement periods. Vertical bars indicate the uncertainty of the budgets (see Appendix).

$-73 \pm 38 \mathrm{~g} \mathrm{C} \mathrm{m}^{-2} \mathrm{a}^{-1}$ at the natural site). Depending on the start of the annual averaging period, the annual NEE is highly variable. This is more pronounced at the drained spruce forest Mooseurach (range between -80 and $-300 \mathrm{~g} \mathrm{C} \mathrm{m}^{-2} \mathrm{a}^{-1}$; Fig. 7a). At the natural site the range of NEE is noticeably smaller; it ranges between -33 and $-73 \mathrm{~g} \mathrm{C} \mathrm{m}^{-2} \mathrm{a}^{-1}$. On average, the observed $\mathrm{CO}_{2}$ uptake at the drained site $\left(-157 \pm 36 \mathrm{~g} \mathrm{C} \mathrm{m}^{-2} \mathrm{a}^{-1}\right)$ was three-times larger than at the natural site $\left(-55 \pm 23 \mathrm{~g} \mathrm{C} \mathrm{m}^{-2} \mathrm{a}^{-1}\right.$; Fig. 7b).

The mean annual net $\mathrm{CO}_{2}$ uptake at the natural bogpine site Schechenfilz is very similar to annual NEE budgets of other temperate and boreal, natural, non-forested bog sites reported in the literature. For example, Lund et al. (2007) determined an NEE of $-21 \mathrm{~g} \mathrm{C} \mathrm{m}^{-2} \mathrm{a}^{-1}$ for a southern Swedish temperate bog site. In a temperate Canadian bog, Lafleur et al. (2003) found an NEE ranging between +10 and $-76 \mathrm{~g} \mathrm{C} \mathrm{m}^{-2} \mathrm{a}^{-1}$, depending on snow coverage in winter and water availability during the growing season. For an Irish blanket bog, an NEE of a very similar range ( -49 and $-61 \mathrm{~g} \mathrm{C} \mathrm{m}^{-2} \mathrm{a}^{-1}$ ) was reported by Sottocornola and Kiely (2005). This comparison implies that the presence of the bog pines does not enhance the annual $\mathrm{CO}_{2}$ uptake compared to non-forested bog sites, with their corresponding larger coverage of grass species.

Studies of the $\mathrm{CO}_{2}$ exchange of drained and afforested peatland sites are rare, and the reported annual budgets are highly variable (see also Introduction). Mostly, drained peatland forests are reported to be strong annual net $\mathrm{CO}_{2}$ sinks $\left(>-150 \mathrm{~g} \mathrm{C} \mathrm{m}^{-2} \mathrm{a}^{-1}\right)$. At some peatland forests sites the net $\mathrm{CO}_{2}$ sink is entirely attributable to the carbon accumulation

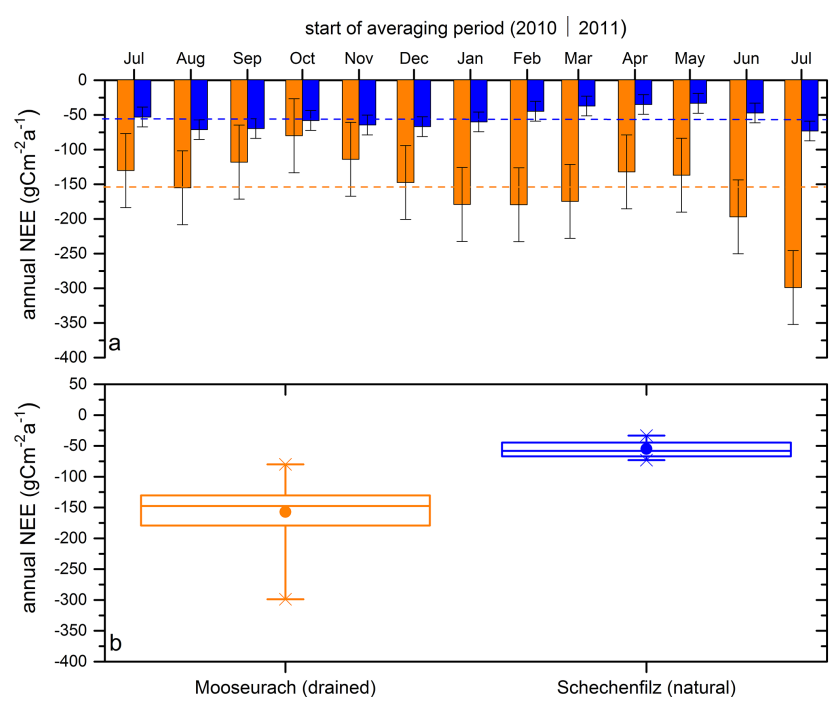

Figure 7. (a) Annual NEE depending on start of averaging period, dashed line illustrates the mean of 13 different averaging periods, the vertical bars present the standard deviation. (b) Box plots illustrate the range (-) of detected annual sums of NEE and their mean $(\bullet)$. The box indicates the 25 th, 75 th and 50 th percentile.

of the trees (Hargreaves et al., 2003; Meyer et al., 2013; von Arnold et al., 2005), but at other sites even the soil is a net $\mathrm{CO}_{2}$ sink (Lohila et al., 2011; Minkkinen et al., 2002). However, for two drained peatland forests, of different age and different nutrient supply, Dunn et al. (2007) and Lohila et al. (2007) found an annual NEE close to zero (+84 and $-58 \mathrm{~g} \mathrm{C} \mathrm{m}^{-2} \mathrm{a}^{-1}$ ). Measurements over 2 years over a boreal drained forest in central Sweden even indicate an annual net $\mathrm{CO}_{2}$ release $\left(+128 \mathrm{~g} \mathrm{C} \mathrm{m}^{-2} \mathrm{a}^{-1}\right.$; Lindroth et al., 1998). Thus a comparison of our results with the carbon budgets from other sites is difficult, because site specific factors (e.g., nutrient supply, annual mean temperature, trees stock) are very different.

\subsection{Seasonal variation of $\mathrm{CO}_{2}$ exchange}

Over the whole 2-year measurement period, the total net $\mathrm{CO}_{2}$ uptake by the drained ecosystem at Mooseurach was $-429 \pm 73 \mathrm{~g} \mathrm{C} \mathrm{m}^{-2}$ and $-126 \pm 45 \mathrm{~g} \mathrm{C} \mathrm{m}^{-2}$ by the natural ecosystem at Schechenfilz (Fig. 8). Seasonal and short-term patterns were very similar at the two sites; the differences in the cumulative $\mathrm{CO}_{2}$ exchange curves are mostly a result of the generally larger component fluxes (GPP and $R_{\text {eco }}$ ) at the drained spruce forest Mooseurach.

In spring, both ecosystems were strong $\mathrm{CO}_{2}$ sinks in both years, in spite of the considerable water table drawdown in March and April 2011. The strong and consistent $\mathrm{CO}_{2}$ uptake in spring is due to the phase-shift in the annual cycle of soil temperatures which are still low in spring and thus limit soil respiration while high radiation levels lead to moderately high photosynthetic activity (Dunn et al., 2007; Griffis 


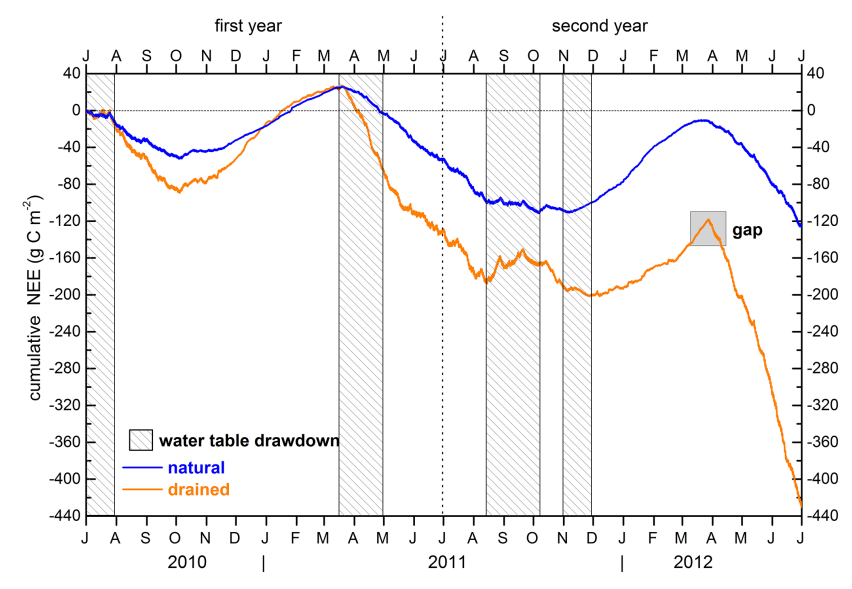

Figure 8. Cumulative NEE at both sites over the whole measurement period (1 July 2010-30 June 2012). The grey shaded box marks a long data gap at the drained site due to power failure. The dotted vertical line shows the end of the first annual cycle. The horizontal dashed line highlights the zero line; negative slope of NEE represents carbon uptake and positive values carbon release. Uncertainty intervals are not shown for clarity.

et al., 2003). However, the carbon uptake rate was markedly stronger at the drained site.

The start of the net uptake season at the natural Schechenfilz site was very similar in spring 2011 and 2012 (midMarch) but, due to a 4-week data gap, the beginning of the growing season at the drained forest Mooseurach could not be detected precisely in 2012 .

During dry and warm conditions in summer (July 2010 and August-September 2011), we observed reduced $\mathrm{CO}_{2}$ uptake which again was more pronounced at the drained site (Fig. 8). At this time soil respiration reaches its maximum because of higher soil temperature. In addition, the photoperiod shortens and in spite of the sunny conditions, vegetation senescence starts leading to lower photosynthetic activity. In this period, the $\mathrm{CO}_{2}$ exchange at the drained site differs considerably between the 2 years. In 2010 we observed continuous $\mathrm{CO}_{2}$ uptake until early October, while in 2011 the $\mathrm{CO}_{2}$ uptake was discontinuous during the warm and dry period between mid-August and mid-October.

Finally, during the unusual sunny and rain-free weather conditions in November 2011 (compare Fig. 3) we observed an extended secondary net uptake period, while the natural bog-pine system stopped carbon uptake in October, similarly to the previous year (Fig. 8). The different NEE response of the two sites can be attributed to differences in tree physiology. The light-dependent photosynthesis of bog pines is highly sensitive to low temperatures, whereas the photosynthesis of Norway spruces is more robust to low temperatures (von Sengbusch, 2002). Thus, the extended period of sunshine at the natural bog-pine site Schechenfilz in November 2011 had no notable influence, as the bog pines had already ceased photosynthetic activity in response to the drop in temperature. In contrast, photosynthesis by the spruces in Mooseurach continued in spite of the relatively low temperatures. Moreover, the combination of a strong water table drawdown (which makes growing conditions more favorable for the spruces), and low soil temperatures (which reduce soil respiration) further enhanced the net carbon uptake at the drained site in late autumn 2011. Overall, despite noticeable water table drawdown at the drained site, the spruces are apparently never water limited. This is additionally indicated by the independence between $\mathrm{CO}_{2}$ exchange and soil moisture (Fig. 5).

A comparison of the pattern of cumulative NEE over the 2 years of measurements illustrates the different response of the $\mathrm{CO}_{2}$ exchange of the drained and the natural peatland ecosystem to changing environmental factors. At the natural bog-pine site, the annual cycles of cumulative NEE were very similar for both years, despite differences in, for example, drought periods between the 2 years. At this site the overall $\mathrm{CO}_{2}$ exchange is more in balance, due to the low growing activity of the bog pines on the one hand, and the suppressed soil emissions caused by high soil water level on the other hand. In contrast, at least the respirative parts of $\mathrm{CO}_{2}$ exchange at the drained spruce site are sensitive to changing environmental factors, like periods of increased temperature and water table drawdown. However, whether warm and dry anomaly periods increase or decrease net carbon uptake at the drained site depends on soil temperature and spruce phenology and thus on the season.

\subsection{Long-term carbon balance}

The results of the 2 years of eddy covariance measurement presented in this study indicate stronger $\mathrm{CO}_{2}$ uptake of the drained bog forest than of the natural bog forest. Currently, the 44-year old spruces almost reach their maximum productivity (Gower et al., 1996), and can compensate the soil carbon efflux. However, this 2-year measurement period can only reflect the current state of the observed ecosystems. Meaningful comparisons between peatland forests and full evaluation of the climate impact of different land uses require a longer-term perspective, and in addition the determination of methane fluxes. However, we do not have any reliable information on methane for this time period. Thus, we attempt to roughly assess the biome carbon balance in its long-term context based on $\mathrm{CO}_{2}$ only. For an unbiased interpretation of the flux measurements at the drained site, we need to validate the impact of drainage and spruce afforestation on the long-term carbon balance. Therefore, peat-loss-induced carbon emissions, as well as the net carbon fixation within the spruce life cycle have to be considered.

Our estimation of the net peat loss is based on survey data from the 1930s which determined a peat thickness of about $4.4 \mathrm{~m}$. Thus, the peat thickness was reduced by approximately $1 \mathrm{~m}$ down to today's $3.4 \mathrm{~m}$ thickness over the last $70-80$ years, resulting in a potential loss rate of 
roughly $1.25-1.4 \mathrm{~cm} \mathrm{a}^{-1}$. The oxidative contribution to the overall subsidence is estimated to be almost $50 \%$, the rest is attributed to peat compaction and consolidation (Armentano and Menges, 1986; Gronlund et al., 2008; Leifeld et al., 2011b). Assuming a constant carbon content of $49.7 \%$ (Fig. 2) and a dry bulk density of $0.15 \mathrm{~g} \mathrm{~cm}^{-3}$ (N. Rosskopf, personal communication, 2012) of the first $20 \mathrm{~cm}$ top-soil layer in the last decades, we estimate a potential mean annual carbon loss to the atmosphere of about $+500 \mathrm{~g} \mathrm{C} \mathrm{m}^{-2} \mathrm{a}^{-1}$. This rough annual carbon loss estimate is based on survey data from the 1930s, and therefore includes a period that started before the site was afforested. Thus, the potential annual peat carbon loss rate at our drained site is perhaps somewhat overestimated, as the carbon loss of peatland used for pasture is potentially larger than of peatlands used for forestry. Our estimate matches the annual carbon loss estimate of a drained mountain bog in the Swiss Alps, drained 119 years ago (Rogiers et al., 2008). This estimate of Rogiers et al. (2008) is based on differences in ash content after combustion of the peat profile. A similar approach was used by Leifeld et al. (2011a), who estimated mean carbon loss rates ranging from +140 to $+490 \mathrm{~g} \mathrm{C} \mathrm{m}^{-2} \mathrm{a}^{-1}$ for two drained pre-Alpine mountain bogs. Kluge et al. (2008) modeled a larger mean annual peat-carbon loss of about $+700 \mathrm{~g} \mathrm{C} \mathrm{m}^{-2} \mathrm{a}^{-1}$ for an agricultural peatland in northeastern Germany. Reported soil emission rates of forested peatlands span a wide range, including our rough estimate. For example, Braekke (1987) determined a carbon loss of a Norwegian boreal drained Scots pine ecosystem of $+250 \mathrm{~g} \mathrm{C} \mathrm{m}^{-2} \mathrm{a}^{-1}$. However, in a later study Breakke and Finer (1991) note that about $+100 \mathrm{~g} \mathrm{C} \mathrm{m}^{-2} \mathrm{a}^{-1}$ are lost in the years immediately after drainage. The smaller emission rate could be explained by a $50 \%$ lower bulk density compared to the drained forest in Mooseurach, albeit the volume of peat loss was about two-times larger in the Scots pine ecosystem. Simola et al. (2012) estimated a mean carbon loss of $+150 \mathrm{~g} \mathrm{C} \mathrm{m}^{-2} \mathrm{a}^{-1}$ at 37 drained forestry peatland sites in central Finland by re-sampling the peat stratum after about 30 years. Between the 37 sites the annual soil carbon flux varied strongly from -200 to $+800 \mathrm{~g} \mathrm{C} \mathrm{m}^{-2} \mathrm{a}^{-1}$. They found no evident relation between the amount of soil carbon flux and site fertility, or post-drainage timber growth. Minkkinen el al. (2007) measured heterotrophic soil respiration fluxes of a similar range between +248 and $+515 \mathrm{~g} \mathrm{C} \mathrm{m}^{-2} \mathrm{a}^{-1}$ at three boreal forestry-drained peatlands. However, in contrast to Simola et al. (2012), they point out that the carbon loss increased with increasing nutrient supply. Furthermore, the strongest carbon loss from peat soil was measured at the most northern site, which is likely attributed to differences in site factors such as substrate quality, nutrient status, and hydrology. Additionally, Armentano and Menges (1986) note that the carbon loss in temperate climate zones is about 10-times larger than in the boreal zone. In summary, the carbon loss estimates from drained and afforested peat are highly variable and likely depend on mean annual temperature and nutrient supply. Both, temperature and nutrient supply are relative high at the drained bog forest in Mooseurach, supporting a relative large carbon loss estimate.

The current standing biomass of the 44-year old forest, above and below ground, was determined by biometry and common allometric relations as $86 \mathrm{tC} \mathrm{ha}^{-1}$ (S. Röhling, personal communication, 2012). In comparison, the estimated potential net carbon loss from peat degradation is approximately $+220 \mathrm{tC} \mathrm{ha}^{-1}$ within the same period of 44 years, resulting in a total net emission of $+134 \mathrm{t} \mathrm{C} \mathrm{ha}^{-1}$. These quantities should be considered as rough estimates to evaluate current measurement results in their long-term context. Currently, the eddy covariance measurements indicate an average annual net $\mathrm{CO}_{2}$ uptake of $-157 \pm 36 \mathrm{~g} \mathrm{C} \mathrm{m}^{-2} \mathrm{a}^{-1}$ (i.e., $\left.1.57 \mathrm{tCha}^{-1} \mathrm{a}^{-1}\right)$. Thus, in this scenario the forest would need almost another 100 years of carbon assimilation at the current rate to offset the net carbon loss of the last 44 years. Because the expected life cycle of the spruces at the drained site is only about 60 years, we must conclude that, in the long-term, the drained bog forest is an overall strong net $\mathrm{CO}_{2}$ source even if the current eddy covariance measurements indicate net $\mathrm{CO}_{2}$ uptake.

Based on published results of methane exchange of drained peatland forests, the contribution of methane to the long-term carbon balance is seen to be negligible. For example, Lohila et al. (2011) measured the minor methane uptake of $-0.09 \mathrm{~g} \mathrm{C} \mathrm{m}^{-2} \mathrm{a}^{-1}$ in a forestry-drained boreal peatland in southern Finland. Other studies indicate a low methane release of between 0 and $+0.12 \mathrm{~g} \mathrm{C} \mathrm{m}^{-2} \mathrm{a}^{-1}$ in temperate and drained coniferous peatland forests of comparable age (von Arnold et al., 2005; Yamulki et al. 2013).

At the natural bog site Schechenfilz, the peat layer as well as the water level were not affected by human interference in the past; therefore the soil conditions are still pristine. Furthermore, the forest is not a plantation, and the age structure of the trees covers a wide range. Hence, it is likely that the carbon exchange of the natural bog forest is close to the long-term balance with a small net accumulation rate. However, due to the high water level at natural bog sites, we have to expect methane emissions which would reduce the carbon uptake budget and due to their larger global warming potential considerably reduce the climate mitigation effect.

According to the literature review of Saarnio et al. (2007) the methane budget of boreal ombrotrophic mires ranges between +1 and $+16 \mathrm{~g} \mathrm{C} \mathrm{m}^{-2} \mathrm{a}^{-1}$. For example, Rinne et al. (2007) determined an annual net methane budget of $+9.4 \mathrm{~g} \mathrm{C} \mathrm{m}^{-2} \mathrm{a}^{-1}$ for an ombrotrophic fen site in southern Finland. At the bog-pine site Schechenfilz the groundwater level is never above the surface, which would enhance methane production. Moreover, the coverage of sedges, which are known to serve as conduits for the methane fluxes from the soil, is low in comparison to non-forested bog sites. Therefore, we expect only small emission rates which which likely not offset the climate mitigation potential of the carbon 
uptake. Thus the natural bog-pine site was a small but stable net carbon sink during the observation period.

\section{Summary and conclusions}

Eddy covariance measurements of NEE over 2 complete annual cycles (July 2010-June 2012) indicate a stronger uptake of $\mathrm{CO}_{2}$ at a drained spruce forest ecosystem at Mooseurach, compared to a natural bog-pine site at Schechenfilz $\left(-130 \pm 31\right.$ and $-300 \pm 66 \mathrm{~g} \mathrm{C} \mathrm{m}^{-2} \mathrm{a}^{-1}$ in Mooseurach and $-53 \pm 28$ and $-73 \pm 38 \mathrm{~g} \mathrm{C} \mathrm{m}^{-2} \mathrm{a}^{-1}$ in Schechenfilz, respectively). Due to the small distance of $10 \mathrm{~km}$ between the sites, differences in the $\mathrm{CO}_{2}$ exchange can be attributed solely to site-specific factors, such as land use history, soil conditions and vegetation composition, rather than to different atmospheric conditions.

At the drained ecosystem, the budgets of both component fluxes, GPP and $R_{\text {eco }}$, are about twice as large as at the natural bog-pine site. The stronger GPP at the drained site can be attributed to the larger PAI. Furthermore, the response of the $\mathrm{CO}_{2}$ flux at the drained spruce forest is much more sensitive to environmental forcing and therefore any variability of the driving factors has a greater impact on the NEE. Whether water table drawdown promotes or reduces net carbon uptake depends on the state of phenology of the spruces and the level of soil respiration, which is strongly related to soil temperature and thus to the season.
The presented eddy covariance measurements can just represent the current state of forest and soil conditions, but $\mathrm{CO}_{2}$ exchange studies of managed peat forest ecosystems need to consider the different stages of ecosystem development. A rough estimate of carbon loss due to drainage and peat degradation resulted in a potential annual carbon loss of $+500 \mathrm{~g} \mathrm{C} \mathrm{m}^{-2} \mathrm{a}^{-1}$ for the previous 70-80 years. Comparing carbon fixation by the spruces and carbon loss from the peat since forest planting, 44 years ago, we roughly determined a total carbon loss of $+134 \mathrm{tC} \mathrm{ha}^{-1}$. Consequently, the spruce forest in Mooseurach would need to grow another 100 years at the present rate to compensate the carbon loss due to peat degradation in former years.

In contrast, the natural bog forest in Schechenfilz is a robust and consistently small $\mathrm{CO}_{2}$ sink. We thus have to conclude that the natural bog-pine forest is a more effective $\mathrm{CO}_{2}$ sink in the long term in spite of a lower uptake rate during the observation period. This study serves to illustrate the potential climate benefits provided by peatland restoration. Overall, $13 \%$ of peatlands in Germany are currently drained for forestry. If the present results turn out to be representative of other drained peatlands in Germany, our results indicate that forested peatland restoration may be an important long-term climate change mitigation measure. 


\section{Appendix A: Uncertainty of the annual sums}

We distinguish between random $(\varepsilon)$ and systematic errors or bias $(\delta)$. The systematic errors need to be further differentiated into full systematic bias and selective bias (Moncrieff et al., 1996). Selective bias affects solely carbon uptake or carbon release and increases when the measurement period is extended. Causes of systematic errors include underestimation of nighttime respiration, high frequency loss, variations of footprint size and orientation (Massman and Lee, 2002; Richardson et al., 2012; Schmid and Lloyd, 1999). Generally, systematic errors cannot be identified by statistical analysis, but known systematic errors are often minimized by correction terms such as the $u_{*}$ criterion to eliminate non-turbulent fluxes, corrections of spectral loss (Moncrieff et al., 2004; Moncrieff et al., 1997) or the rejection of data not representing the target area. However, we are not able to prevent all systematic errors, particularly those whose origin or behavior are not sufficiently known. Concerning the site comparison we can assume that the impact of systematic errors is relatively small, as the flux calculation, post-processing (rejection criteria) and gap-filling were conducted in the same way (with the exception of the footprint analysis at the natural site). Thus, any bias due to data processing is expected to be very similar at both sites. However, two different measurement devices were used for $\mathrm{H}_{2} \mathrm{O}$ - and $\mathrm{CO}_{2}$-flux measurements (open-path (LI7500, Li-Cor) at the natural site and closed-path (LI7200, Li-Cor) at the drained site), which may lead to a biased site comparison. Based on a study of Burba et al. (2010) and Burba et al. (2009), $\mathrm{CO}_{2}$ and latent-heat fluxes measured by LI7500 and LI7200 show a very good agreement. The slope of the linear regression between latent-heat and $\mathrm{CO}_{2}$ fluxes measured with these two devices for several months is almost one, and the coefficient of determination is better than 0.96 . Thus, the expected bias is negligible and is not addressed in the estimation of uncertainty for the site comparison.
Random errors cannot be corrected for but are identified by statistical analyses and often decrease with extended data sets. We estimated the gap-filling uncertainty using 10000 bootstrap samples for $R_{\text {eco }}$ and GPP estimations, resulting in a gap-filling uncertainty of $\pm 30.7 \mathrm{~g} \mathrm{C} \mathrm{m}^{-2} \mathrm{a}^{-1}$ in the first measurement year and $\pm 65.9 \mathrm{~g} \mathrm{C} \mathrm{m}^{-2} \mathrm{a}^{-1}$ in the second year at the drained site. The gap-filling uncertainty based on data from the natural site is \pm 27.8 and $\pm 38.1 \mathrm{~g} \mathrm{C} \mathrm{m}^{-2} \mathrm{a}^{-1}$ for the two periods, respectively.

Random errors of measured fluxes are caused by footprint variability, errors of turbulence sampling and instrument errors (Richardson et al., 2012). The errors of turbulence sampling can be determined by the variance of the covariance, including auto- and cross-covariance terms, following Finkelstein and Sims (2001). This error estimation is implemented in some eddy covariance flux processing software packages (e.g., TK3; Mauder et al., 2013).

The mean error of turbulence sampling is $\pm 2.6 \mathrm{~g} \mathrm{C} \mathrm{m}^{-2} \mathrm{a}^{-1}$ in the first year, and $\pm 3.1 \mathrm{~g} \mathrm{C} \mathrm{m}^{-2} \mathrm{a}^{-1}$ in the second year at the drained site, and $\pm 1.5 \mathrm{~g} \mathrm{C} \mathrm{m}^{-2} \mathrm{a}^{-1}$ and $\pm 2.5 \mathrm{~g} \mathrm{C} \mathrm{m}^{-2} \mathrm{a}^{-1}$ at the natural site. The uncertainty due to footprint variation and instrument errors could not be estimated accurately in the present project, but based on comparative estimates in the literature (e.g., Dragoni et al., 2007) we expect them to be small in comparison to the gap-filling error.

The random error of measured and gap-filled fluxes were combined by quadrative error propagation (e.g., Richardson et al., 2012; Richardson and Hollinger, 2007), resulting in a negligible contribution of the error induced by turbulence sampling. Thus, random uncertainty of the cumulative $\mathrm{NEE}$ at the drained forest in Mooseurach was determined as $\pm 30.7 \mathrm{~g} \mathrm{C} \mathrm{m}^{-2} \mathrm{a}^{-1}$ in the first year and $\pm 65.6 \mathrm{~g} \mathrm{C} \mathrm{m}^{-2} \mathrm{a}^{-1}$ in the second year, and amounted to 40 and $22 \%$ of the total annual NEE. At the natural site Schechenfilz, the random uncertainty of annual NEE is \pm 27.8 and $\pm 38.1 \mathrm{~g} \mathrm{C} \mathrm{m}^{-2} \mathrm{a}^{-1}$ for the two periods, respectively, or 47 and $52 \%$ of the total budgets.

Even if an overall uncertainty of about $50 \%$ were assumed at both sites, the annual $\mathrm{CO}_{2}$ uptake is invariably stronger at the drained site. 
Acknowledgements. We gratefully acknowledge the Thünen Institute (TI) for funding the project Organic Soils, and the Bavarian Environment Agency for funding the project Effect of peatland restoration on climate change - Assessment of mitigation potential of peatland restoration in Bavaria within framework of Klip2020. The Schechenfilz site is additionally part of the TERENO and ICOS-ecosystems projects, funded by the BMBF and the Helmholtz Association. We acknowledge support by the Deutsche Forschungsgemeinschaft and Open Access Publishing Fund of Karlsruhe Institute of Technology. We thank Steffi Röhling (Technical University of Munich Center of Life and Food Sciences Weihenstephan, Chair for Forest Growth and Yield) and Niko Rosskopf (Humboldt University Berlin, Faculty of Agriculture and Horticulture, Department of Crop and Animal Sciences) who provided their data of forest growth and soil parameters, respectively. We thank Enrico Frahm, Bärbel Tiemeyer and Michel Bechtold (Thünen Institute Braunschweig, Institute of Climate-Smart Agriculture) for running several mini-diver gauges to measure water table fluctuations at both sites and providing their data. We acknowledge Stephan Thiel, Katja Heidbach and Elisabeth Eckart for perfect field work collaboration and Matthias Mauder for his valuable comments on the manuscript. Access to the sites was made possible by Christof Bosch, Mooseurach; the NORIS-estate and the District Government of Upper Bavaria.

This paper is dedicated to the memory of Peter Werle, who led the KIT part of the Schechenfilz project until he tragically passed away in September 2013.

The service charges for this open access publication have been covered by a Research Centre of the Helmholtz Association.

Edited by: A. Freibauer

\section{References}

Alm, J., Saarnio, S., Nykanen, H., Silvola, J., and Martikainen, P. J.: Winter $\mathrm{CO}_{2}, \mathrm{CH}_{4}$ and $\mathrm{N}_{2} \mathrm{O}$ fluxes on some natural and drained boreal peatlands, Biogeochemistry, 44, 163-186, doi:10.1023/A:1006074606204, 1999a.

Alm, J., Schulman, L., Walden, J., Nykanen, H., Martikainen, P. J., and Silvola, J.: Carbon balance of a boreal bog during a year with an exceptionally dry summer, Biogeochemistry, 80, 161-174, doi:10.1890/0012-9658(1999)080[0161:CBOABB]2.0.CO;2, 1999b.

Armentano, T. V. and Menges, E. S.: Patterns of Change in the Carbon Balance of Organic Soil-Wetlands of the Temperate Zone, J. Ecol., 74, 755-774, doi:10.2307/2260396, 1986.

Arneth, A., Kurbatova, J., Kolle, O., Shibistova, O. B., Lloyd, J., Vygodskaya, N. N., and Schulze, E. D.: Comparative ecosystematmosphere exchange of energy and mass in a European Russian and a central Siberian bog II. Interseasonal and interannual variability of $\mathrm{CO}_{2}$ fluxes, Tellus B., 54, 514-530, doi:10.1034/j.1600-0889.2002.01349.x, 2002.

Aubinet, M., Feigenwinter, C., Heinesch, B., Laffineur, Q., Papale, D., Reichstein, M., Rinne, J., and van Gorsel, E.: Nighttime Flux Correction, in: Eddy Covariance A Practical Guide to Measurment and Data Analysis, edited by: Aubinet, M., Vesala, T., and Papale, D., Springer, 133-157, 2012.
Aurela, M., Riutta, T., Laurila, T., Tuovinen, J. P., Vesala, T., Tuittila, E. S., Rinne, J., Haapanala, S., and Laine, J.: $\mathrm{CO}_{2}$ exchange of a sedge fen in southern Finland - The impact of a drought period, Tellus B, 59, 826-837, doi:10.1111/j.16000889.2007.00309.x, 2007.

Aurela, M., Lohila, A., Tuovinen, J. P., Hatakka, J., Riutta, T., and Laurila, T.: Carbon dioxide exchange on a northern boreal fen, Boreal. Environ. Res., 14, 699-710, 2009.

Baldocchi, D. D., Hicks, B. B., and Meyers, T. P.: Measuring Biosphere-Atmosphere Exchanges of Biologically Related Gases with Micrometeorological Methods, Ecology, 69, 13311340, doi:10.2307/1941631, 1988.

Braekke, F. H.: Nutrient Relationships in Forest Stands - Effects of Drainage and Fertilization on Surface Peat Layers, Forest Ecol. Manage., 21, 269-284, doi:10.1016/0378-1127(87)90048X, 1987.

Braekke, F. H. and Finer, L.: Fertilization Effects on Surface Peat of Pine Bogs, Scand. J. Forest Res., 6, 433-449, doi:10.1080/02827589109382681, 1991.

Bubier, J., Crill, P., Mosedale, A., Frolking, S. and Linder, E.: Peatland responses to varying interannual moisture conditions as measured by automatic $\mathrm{CO}_{2}$ chambers, Global Biogeochem. Cy., 17, 1066, doi:10.1029/2002GB001946, 2003a.

Bubier, J. L., Bhatia, G., Moore, T. R., Roulet, N. T., and Lafleur, P. M.: Spatial and temporal variability in growing-season net ecosystem carbon dioxide exchange at a large peatland in Ontario, Canada, Ecosystems, 6, 353-367, doi:10.1007/s10021003-0125-0, 2003b.

Burba, G., Furtaw, M. D., McDermitt, D. K., and Eckles, R.: Combining the strengths of open-path and closed-path designs into a single $\mathrm{CO}_{2} / \mathrm{H}_{2} \mathrm{O}$ gas analyzer, American Geophysical Union Fall Meeting, San Francisco, California, USA, 14-18 December, 2009.

Burba, G. G., McDermitt, D. K., Anderson, D. J., Furtaw, M. D., and Eckles, R. D.: Novel design of an enclosed $\mathrm{CO}_{2} / \mathrm{H}_{2} \mathrm{O}$ gas analyser for eddy covariance flux measurements, Tellus B, 62, 743-748, doi:10.1111/j.1600-0889.2010.00468.x, 2010.

Byrne, K. A., Chojnicki, B., Christensen, T. R., Drösler, M., Freibauer, A., Friborg, T., Frolking, S., Lindroth, A., Mailhammer, J., Malmer, N., Selin, P., Turunen, J., Valentini, R., and Zetterberg, L.: EU peatlands: Current carbon stocks and trace gas fluxes, CarboEurope-GHG Concerted Action-Synthesis of the European Greenhouse Gas Budget, Carboeurope GHG, Report 4/2004, 58 pp., 2004.

Cannell, M. G. R., Dewar, R. C., and Pyatt, D. G.: Conifer Plantations on Drained Peatlands in Britain - A Net Gain Or Loss of Carbon, Forestry, 66, 353-369, doi:10.1093/forestry/66.4.353, 1993.

Clymo, R. S.: The Limits to Peat Bog Growth, Philos. T. R. Soc. B, 303, 605-654, doi:10.1098/rstb.1984.0002, 1984.

Couwenberg, J.: Greenhouse gas emissions from managed peat soils: is the IPCC reporting guidance realistic?, Mires Peat, 8 , $1-10,2011$.

Dragoni, D., Schmid, H. P., Grimmond, C. S. B., and Loescher, H. W.: Uncertainty of annual net ecosystem productivity estimated using eddy covariance flux measurements, J. Geophys. Res.-Atmos., 112, D17102, doi:10.1029/2006JD008149, 2007.

Drösler, M., Freibauer, A., Christensen, T., and Friborg, T.: Observations and status of peatland greenhouse gas emissions in $\mathrm{Eu}-$ 
rope, in: The Continental-Scale Greenhouse Gas Balance of Europe, edited by: Dolman, A. J., Freibauer, A., and Valentini, R., Springer, New York, 243-261, 2008.

Dunn, A. L., Barford, C. C., Wofsy, S. C., Goulden, M. L., and Daube, B. C.: A long-term record of carbon exchange in a boreal black spruce forest: means, responses to interannual variability, and decadal trends, Glob. Change Biol., 13, 577-590, doi:10.1111/j.1365-2486.2006.01221.x, 2007.

Erwin, K. L.: Wetlands and global climate change: the role of wetland restoration in a changing world, Wetlands Ecol. Manage., 17, 71-84, doi:10.1007/s11273-008-9119-1, 2009.

Falge, E., Baldocchi, D., Olson, R., Anthoni, P., Aubinet, M., Bernhofer, C., Burba, G., Ceulemans, R., Clement, R., Dolman, H., Granier, A., Gross, P., Grunwald, T., Hollinger, D., Jensen, N. O., Katul, G., Keronen, P., Kowalski, A., Lai, C. T., Law, B. E., Meyers, T., Moncrieff, H., Moors, E., Munger, J. W., Pilegaard, K., Rannik, U., Rebmann, C., Suyker, A., Tenhunen, J., Tu, K., Verma, S., Vesala, T., Wilson, K., and Wofsy, S.: Gap filling strategies for defensible annual sums of net ecosystem exchange, Agr. Forest Meteorol., 107, 43-69, doi:10.1016/S01681923(00)00225-2, 2001.

Finkelstein, P. L. and Sims, P. F.: Sampling error in eddy correlation flux measurements, J. Geophys. Res.-Atmos., 106, 3503-3509, doi:10.1029/2000JD900731, 2001.

Foken, T., Aubinet, M., and Leuning, R.: The Eddy Covariance Method, in: Eddy Covariance A Practical Guide to Measurment and Data Analysis, edited by: Aubinet, M., Vesala, T., and Papale, D., Springer, 1-19, 2012.

Frolking, S. E. and Roulet, N. T.: Holocene radiative forcing impact of northern peatland carbon accumulation and methane emissions, Glob. Change Biol., 13, 1079-1088, doi:10.1111/j.13652486.2007.01339.x, 2007.

Gorham, E.: Northern Peatlands - Role in the Carbon-Cycle and Probable Responses to Climatic Warming, Ecol. Appl., 1, 182195, doi:10.2307/1941811, 1991.

Goulden, M. L. and Crill, P. M.: Automated measurements of $\mathrm{CO}_{2}$ exchange at the moss surface of a black spruce forest, Tree Physiol., 17, 537-542, 1997.

Goulden, M. L., Munger, J. W., Fan, S. M., Daube, B. C., and Wofsy, S. C.: Measurements of carbon sequestration by longterm eddy covariance: Methods and a critical evaluation of accuracy, Glob. Change Biol., 2, 169-182, doi:10.1111/j.13652486.1996.tb00070.x, 1996.

Gower, S. T., McMurtrie, R. E., and Murty, D.: Aboveground net primary production decline with stand age: Potential causes, Trends Ecol. Evol., 11, 378-382, doi:10.1016/01695347(96)10042-2, 1996

Griffis, T. J., Black, T. A., Morgenstern, K., Barr, A. G., Nesic, Z., Drewitt, G. B., Gaumont-Guay, D., and McCaughey, J. H.: Ecophysiological controls on the carbon balances of three southern boreal forests, Agr. Forest Meteorol., 117, 53-71, doi:10.1016/S0168-1923(03)00023-6, 2003.

Gronlund, A., Hauge, A., Hovde, A., and Rasse, D. P.: Carbon loss estimates from cultivated peat soils in Norway: a comparison of three methods, Nutr. Cycl. Agroecosyst., 81, 157-167, doi:10.1007/s10705-008-9171-5, 2008.

Hargreaves, K. J., Milne, R., and Cannell, M. G. R.: Carbon balance of afforested peatland in Scotland, Forestry, 76, 299-317, doi:10.1093/forestry/76.3.299, 2003.
Hendriks, D. M. D., van Huissteden, J., Dolman, A. J., and van der Molen, M. K.: The full greenhouse gas balance of an abandoned peat meadow, Biogeosciences, 4, 411-424, doi:10.5194/bg-4411-2007, 2007.

Houghton, J. T., Jenkins, G. J., and Ephraums, J. J.: Climate Change. The IPCC scientific assessment, Cambridge University Press, Cambridge, 1990.

Kluge, B., Wessolek, G., Facklam, M., Lorenz, M., and Schwarzel, $\mathrm{K}$.: Long-term carbon loss and $\mathrm{CO}_{2}-\mathrm{C}$ release of drained peatland soils in northeast Germany, Eur. J. Soil Sci., 59, 1076-1086, doi:10.1111/j.1365-2389.2008.01079.x, 2008.

Kormann, R. and Meixner, F. X.: An analytical footprint model for non-neutral stratification, Bound.-Lay. Meteor., 99, 207-224, doi:10.1023/A:1018991015119, 2001.

Lafleur, P. M., Roulet, N. T., Bubier, J. L., Frolking, S., and Moore, T. R.: Interannual variability in the peatland-atmosphere carbon dioxide exchange at an ombrotrophic bog, Global Biogeochem. Cy., 17, 1036, doi:10.1029/2002GB001983, 2003.

Lafleur, P. M., Moore, T. R., Roulet, N. T., and Frolking, S.: Ecosystem respiration in a cool temperate bog depends on peat temperature but not water table, Ecosystems, 8, 619-629, doi:10.1007/s10021-003-0131-2, 2005.

Leifeld, J., Gubler, L., and Grunig, A.: Organic matter losses from temperate ombrotrophic peatlands: an evaluation of the ash residue method, Plant Soil, 341, 349-361, doi:10.1007/s11104010-0649-y, 2011a.

Leifeld, J., Muller, M., and Fuhrer, J.: Peatland subsidence and carbon loss from drained temperate fens, Soil Use Manage., 27, 170-176, doi:10.1111/j.1475-2743.2011.00327.x, 2011b.

Lindroth, A., Grelle, A., and Moren, A. S.: Long-term measurements of boreal forest carbon balance reveal large temperature sensitivity, Glob. Change Biol., 4, 443-450, doi:10.1046/j.13652486.1998.00165.x, 1998.

Lloyd, J. and Taylor, J. A.: On the Temperature-Dependence of Soil Respiration, Funct. Ecol., 8, 315-323, 1994.

Lohila, A., Laurila, T., Aro, L., Aurela, M., Tuovinen, J. P., Laine, J., Kolari, P., and Minkkinen, K.: Carbon dioxide exchange above a 30-year-old Scots pine plantation established on organic-soil cropland, Boreal. Environ. Res., 12, 141-157, 2007.

Lohila, A., Minkkinen, K., Aurela, M., Tuovinen, J. P., Penttila, T., Ojanen, P., and Laurila, T.: Greenhouse gas flux measurements in a forestry-drained peatland indicate a large carbon sink, Biogeosciences, 8, 3203-3218, doi:10.5194/bg-8-3203-2011, 2011.

Lund, M., Lindroth, A., Christensen, T. R., and Strom, L.: Annual $\mathrm{CO}_{2}$ balance of a temperate bog, Tellus B., 59, 804-811, doi:10.1111/j.1600-0889.2007.00303.x, 2007.

Maljanen, M., Sigurdsson, B., Guomundsson, J., Oskarsson, H., Huttunen, J., and Martikainen, P.: Greenhouse gas balances of managed peatlands in the Nordic countries - present knowledge and gaps, Biogeosciences, 7, 2711-2738, doi:10.5194/bg7-2711-2010, 2010.

Massman, W. J. and Lee, X.: Eddy covariance flux corrections and uncertainties in long-term studies of carbon and energy exchanges, Agr. Forest Meteorol., 113, 121-144, doi:10.1016/S0168-1923(02)00105-3, 2002.

Mauder, M. and Foken, T.: Documentation and Instruction Manual of the Eddy-Covariance Software Package TK3, Arbeitsergebnisse Nr. 42, University of Bayreuth, Department of Micrometeorology, 125 pp., 2011. 
Mauder, M., Cuntz, M., Druee, C., Graf, A., Rebmann, C., Schmid, H. P., Schmidt, M., and Steinbrecher, R.: A strategy for quality and uncertainty assessment of long-term eddycovariance measurements, Agr. Forest Meteorol., 169, 122-135, doi:10.1016/j.agrformet.2012.09.006, 2013.

Meyer, A., Tarvainen, L., Nousratpour, A., Bjork, R., Ernfors, M., Grelle, A., Klemedtsson, A., Lindroth, A., Rantfors, M., Rutting, T., Wallin, G., Weslien, P., and Klemedtsson, L.: A fertile peatland forest does not constitute a major greenhouse gas sink, Biogeosciences, 10, 7739-7758, doi:10.5194/bg-10-7739-2013, 2013.

Minkkinen, K., Korhonen, R., Savolainen, I., and Laine, J.: Carbon balance and radiative forcing of Finnish peatlands 1900-2100 the impact of forestry drainage, Glob. Change Biol., 8, 785-799, doi:10.1046/j.1365-2486.2002.00504.x, 2002.

Minkkinen, K., Laine, J., Shurpali, N. J., Makiranta, P., Alm, J., and Penttila, T.: Heterotrophic soil respiration in forestry-drained peatlands, Boreal. Environ. Res., 12, 115-126, 2007.

Moffat, A. M., Papale, D., Reichstein, M., Hollinger, D. Y., Richardson, A. D., Barr, A. G., Beckstein, C., Braswell, B. H., Churkina, G., Desai, A. R., Falge, E., Gove, J. H., Heimann, M., Hui, D. F., Jarvis, A. J., Kattge, J., Noormets, A., and Stauch, V. J.: Comprehensive comparison of gap-filling techniques for eddy covariance net carbon fluxes, Agr. Forest Meteorol., 147, 209232, doi:10.1016/j.agrformet.2007.08.011, 2007.

Moncrieff, J., Clement, R., Finnigan, J. J., and Meyers, T.: Averaging, Detrending, and Filtering of Eddy Covariance Time Series, in: Handbook of Micrometeorology: A Guide for Surface Flux Measurement and Analysis, Springer Netherlands, 7-31, 2004.

Moncrieff, J. B., Massheder, J. M., deBruin, H., Elbers, J., Friborg, T., Heusinkveld, B., Kabat, P., Scott, S., Soegaard, H., and Verhoef, A.: A system to measure surface fluxes of momentum, sensible heat, water vapour and carbon dioxide, J. Hydrol., 189, 589-611, doi:10.1016/S0022-1694(96)03194-0, 1997.

Moncrieff, J. B., Malhi, Y., and Leuning, R.: The propagation of errors in long-term measurements of land-atmosphere fluxes of carbon and water, Glob. Change Biol., 2, 231-240, doi:10.1111/j.1365-2486.1996.tb00075.x, 1996.

Moore, C. J.: Frequency-Response Corrections for EddyCorrelation Systems, Bound.-Layer Meteor., 37, 17-35, doi:10.1007/BF00122754, 1986.

Moore, T. R., Roulet, N. T., and Waddington, J. M.: Uncertainty in predicting the effect of climatic change on the carbon cycling of Canadian peatlands, Clim. Change, 40, 229-245, doi:10.1023/A:1005408719297, 1998.

Ojanen, P., Minkkinen, K., and Penttila, T.: The current greenhouse gas impact of forestry-drained boreal peatlands, Forest Ecol. Manage., 289, 201-208, doi:10.1016/j.foreco.2012.10.008, 2013.

Reichstein, M., Falge, E., Baldocchi, D., Papale, D., Aubinet, M., Berbigier, P., Bernhofer, C., Buchmann, N., Gilmanov, T., Granier, A., Grunwald, T., Havrankova, K., Ilvesniemi, H., Janous, D., Knohl, A., Laurila, T., Lohila, A., Loustau, D., Matteucci, G., Meyers, T., Miglietta, F., Ourcival, J. M., Pumpanen, J., Rambal, S., Rotenberg, E., Sanz, M., Tenhunen, J., Seufert, G., Vaccari, F., Vesala, T., Yakir, D., and Valentini, R.: On the separation of net ecosystem exchange into assimilation and ecosystem respiration: review and improved algorithm, Glob. Change Biol., 11, 1424-1439, doi:10.1111/j.1365-2486.2005.001002.x, 2005.
Richardson, A. D. and Hollinger, D. Y.: A method to estimate the additional uncertainty in gap-filled NEE resulting from long gaps in the $\mathrm{CO}_{2}$ flux record, Agr. Forest Meteorol., 147, 199-208, doi:10.1016/j.agrformet.2007.06.004, 2007.

Richardson, A. D., Aubinet, M., Barr, A., Hollinger, D., Ibrom, A., Lasslop, G., and Reichstein, M.: Uncertainty Quantification, in: Eddy Covariance A Practical Guide to Measurement and Data Analysis, edited by: Aubinet, M., Vesala, T., and Papale, D., Springer, 173-209, 2012.

Rinne, J., Riutta, T., Pihlatie, M., Aurela, M., Haapanala, S., Tuovinen, J. P., Tuittila, E. S., and Vesala, T.: Annual cycle of methane emission from a boreal fen measured by the eddy covariance technique, Tellus B, 59, 449-457, doi:10.1111/j.16000889.2007.00261.x, 2007.

Rogiers, N., Conen, F., Furger, M., Stockli, R., and Eugster, W.: Impact of past and present land-management on the C-balance of a grassland in the Swiss Alps, Glob. Change Biol., 14, 2613 2625, doi:10.1111/j.1365-2486.2008.01680.x, 2008.

Rydin, H. and Jeglum, J. K.: The Biology of Peatlands, 2nd Edition, Oxford University Press, Oxford, United Kingdom, 343 pp., 2013.

Saarnio, S., Morero, M., Shurpali, N.J., Tuittila, E.S., Makila, M. and Alm, J.: Annual $\mathrm{CO}_{2}$ and $\mathrm{CH}_{4}$ fluxes of pristine boreal mires as a background for the lifecycle analyses of peat energy, Boreal. Environ. Res., 12, 101-113, 2007.

Schmid, H. P. and Lloyd, C. R.: Spatial representativeness and the location bias of flux footprints over inhomogeneous areas, Agr. Forest Meteorol., 93, 195-209, doi:10.1016/S01681923(98)00119-1, 1999.

Schmid, H. P., Su, H. B., Vogel, C. S., and Curtis, P. S.: Ecosystematmosphere exchange of carbon dioxide over a mixed hardwood forest in northern lower Michigan, J. Geophys. Res.-Atmos., 108, 4417, doi:10.1029/2002JD003011, 2003.

Simola, H., Pitkanen, A., and Turunen, J.: Carbon loss in drained forestry peatlands in Finland, estimated by re-sampling peatlands surveyed in the 1980s, Eur. J. Soil Sci., 63, 798-807, doi:10.1111/j.1365-2389.2012.01499.x, 2012.

Sottocornola, M. and Kiely, G.: An Atlantic blanket bog is a modest $\mathrm{CO}_{2}$ sink, Geophys. Res. Lett., 32, L23804, doi:10.1029/2005GL024731, 2005.

Tolonen, K. and Turunen, J.: Accumulation rates of carbon in mires in Finland and implications for climate change, Holocene, 6, 171-178, doi:10.1177/095968369600600204, 1996.

Turunen, J., Tomppo, E., Tolonen, K., and Reinikainen, A.: Estimating carbon accumulation rates of undrained mires in Finland - application to boreal and subarctic regions, Holocene, 12, 6980, doi:10.1191/0959683602hl522rp, 2002.

Von Arnold, K., Weslien, P., Nilsson, M., Svensson, B. H., and Klemedtsson, L.: Fluxes of $\mathrm{CO}_{2}, \mathrm{CH}_{4}$ and $\mathrm{N}_{2} \mathrm{O}$ from drained coniferous forests on organic soils, Forest Ecol. Manage., 210, 239-254, doi:10.1016/j.foreco.2005.02.031, 2005.

Von Post, L.: Sveriges geologiska undersoknings torvinventering och nagre av dess hittills vunna resultat, Sr Mosskulturfor, Tidstr $1,1-27,1922$.

Von Sengbusch, P.: Untersuchungen zur Ökologie von Pinus rotundata LINK (Moor-Kiefer) im Südschwarzwald, University of Freiburg, 151 pp., 2002.

Webb, E. K., Pearman, G. I., and Leuning, R.: Correction of Flux Measurements for Density Effects Due to Heat and 
Water-Vapor Transfer, Q. J. R. Meteorol. Soc., 106, 85-100, doi:10.1002/qj.49710644707, 1980.

Wilczak, J. M., Oncley, S. P., and Stage, S. A.: Sonic anemometer tilt correction algorithms, Bound.-Lay. Meteor., 99, 127-150, doi:10.1023/A:1018966204465, 2001.
Yoshikawa, K., Overduin, P. P., and Harden, J. W.: Moisture content measurements of moss (Sphagnum spp.) using commercial sensors, Permafrost Perigl. Process., 15, 309-318, doi:10.1002/ppp.505, 2004. 